\title{
The Influence of Urban Conditions on the Phenology of Aesculus hippocastanum L. Using the Example of Wroclaw (Poland)
}

\author{
Iwona Dominika Orzechowska-Szajda *D, Robert Krzysztof Sobolewski, Joanna Lewandowska, \\ Paulina Kowalska and Robert Kalbarczyk
}

Institute of Landscape Architecture, Wrocław University of Environmental and Life Sciences, Grunwaldzaka 55, 50-375 Wrocław, Poland; robert.sobolewski.lubawka@gmail.com (R.K.S.); jlewandowska93@gmail.com (J.L.); paulinakowalska366@gmail.com (P.K.); robert.kalbarczyk@upwr.edu.pl (R.K.)

* Correspondence: iwona.orzechowska-szajda@upwr.edu.pl; Tel.: +48-71-320-5561

Received: 5 October 2020; Accepted: 23 November 2020; Published: 26 November 2020

\begin{abstract}
The differences in plant phenology between rural and urban areas are the subject of research conducted all over the world. There are few studies aimed at assessing the impact of the urban heat island on plant vegetation only in urban areas. The aim of this study is to assess the impact of the distance from the city center and the form of land cover on the phenological development of trees using the example of the horse chestnut (Aesculus hippocastanum L.). The research area covered the entire city of Wrocław. In order to best capture the impact of the distance from the city center on the rate of changes of individual phenophases, 3 areas were designated-at a distance of $1 \mathrm{~km}$, $2 \mathrm{~km}$ and $5 \mathrm{~km}$. The study assessed the average duration of individual phenological phases along with the variability characteristics for leafing, flowering and fruiting in relation to the designated zones and classified forms of land cover based on mean value $(\bar{x})$ and standard deviation $( \pm \mathrm{SD})$ in individual weeks of the year. For the leafing and flowering phases, the frequency of the occurrence of phases in individual weeks of the year was analyzed in relation to the designated zones and classified land use methods. The results obtained on the basis of phenological observations carried out in 2017 in Wroclaw confirmed the extension of the period of vegetation in the city center in relation to its peripheries. Trees growing in road lanes entered the vegetation period later and defoliated faster, which confirms the negative impact of street conditions on the development of trees in urban space. Thus, the growing season in road lanes is shorter and due to the 1-year observation period, it is justified to conduct further observations.
\end{abstract}

Keywords: horse chestnut; urban heat island; phenological observations; city climate

\section{Introduction}

There are numerous studies around the world showing the impact of urbanization and global climate change on the environment [1-11]. Urban conditions can significantly influence plant phenology by modifying the hydrological regime or the local climate [12]. Škvareninová et al. [13] or Ffrench-Constanti et al. [14] also proved the influence of artificial lighting on the phenology of urban plants. Ballester et al. [15], Seto et al. [16] and Klemm et al. [17] showed that urbanized regions can be much warmer than the surrounding rural regions, creating a so-called urban heat island (UHI). McCarthy et al. [18] or Oleson et al. [19] emphasize the topicality and importance of research on UHI and related aspects, especially because the percentage of the world's population inhabiting urban areas is increasing and high temperatures can affect the thermal comfort and well-being of the urban inhabitants [20]. Cities are an important area of phenological research because their warmer conditions 
can help to assess the potential effects of climate change on plants $[4,21,22]$. Temperature trend analyses over 100 years in some cities in the United States showed that the temperature in urban areas from 1940 to 2000, increased by an average of $0.5-3.0^{\circ} \mathrm{C}$ [23]. Cardelino and Chameides [24] showed that in Atlanta, in the 15 years to 1990, there was an increase in air temperature of about $2{ }^{\circ} \mathrm{C}$ during the summer period due to the progressive urbanization and the accompanying intensification of the urban heat island. Increasing thermal contrast between the city center and the city peripheries was also noted in European countries, including in Athens [25] or in London [26].

However, little is known about the spatial and temporal variability of plants as a result of the interaction between urban conditions and UHI [27]. The increase in temperature caused by the urban heat island affects the phenology of plants both within and around cities [28-31], unfortunately, the ecological impact of urban heat island remains poorly understood in scientific research [27,31,32].

The differences in plant phenology between rural and urban areas are the subject of research conducted all over the world, both in Europe [10,21,29,30,33,34] and in North America [12,33-36], South America [30], Asia [33,37-39] or Africa [33]. However, these studies, which are mainly based on the observations of one or several species, do not aim to capture the variability within cities [21,40]. There are few studies aimed at assessing the impact of the urban heat island on plant vegetation only in urban areas $[23,27,34,41]$.

Due to the difficulty and time consuming nature of conducting phenological observations, many researchers rely on satellite remote sensing to investigate spatial variability [27,35,42], limiting themselves only to capturing the beginning and end of the growing season. Moreover, these studies omit the assessment of the influence of city geometry, land use or tree growth conditions on their phenology, which is an important gap in phenological research, as emphasized by Jochner et al. [29] and Walker et al. [43], basing their observations on only one type of space, for example, forest areas, as did Fisher et al. [44] or Elmore et al. [42]. On the other hand, Zipper et al. [27] took into account two types of areas-wooded and sodded areas. Taking into account the spatial aspect is of particular importance in the context of the results of Yang et al. [45] or Masiero and Souza [46], showing the influence of the type of urban area on thermal conditions.

The aim of this study is to assess the impact of the distance from the city center and the form of land cover (surrounding area) on the phenological development of trees using the example of the horse chestnut (Aesculus hippocastanum L.).

\section{Materials and Methods}

\subsection{The Range of Research}

Wrocław is located in south-western Poland, in the center of the Silesian Lowland (51_ N, 17_E) on the Odra River and its four tributaries (Figure 1). It is the historical capital of Silesia and Lower Silesia. The altitude above sea level ranges from 105 to $145 \mathrm{~m}$. The city has approximately 640,000 inhabitants and its area is $293 \mathrm{~km}^{2}$, including $31.4 \%$ built-up areas, $36.6 \%$ green areas and $28.9 \%$ agricultural areas and water $(3.1 \%)$.

Wrocław is located in the temperate climate zone of the northern latitude, in a transitional type of climate, subject to oceanic and continental influences. The average annual air temperature in Wrockaw is $9.0^{\circ} \mathrm{C}$, with lows in the coldest month (January) of around $-0.4^{\circ} \mathrm{C}$ and highs in the hottest month (July) of around $18.8^{\circ} \mathrm{C}$. The amplitude of the annual temperature, which is a measure of the degree of climate continentalism, is $19.2^{\circ} \mathrm{C}$. Atmospheric precipitation occur on 167 days a year and the average annual rainfall in the years 1901-2000 is $583 \mathrm{~mm}$ [47]. The vegetation period in Wrocław in the years 1951-2014 was 237.6 days on average and the sum of active temperatures was 174.4 days, which qualifies Wrocław as one of the cities with the longest vegetation period in the south-western Poland [48]. 


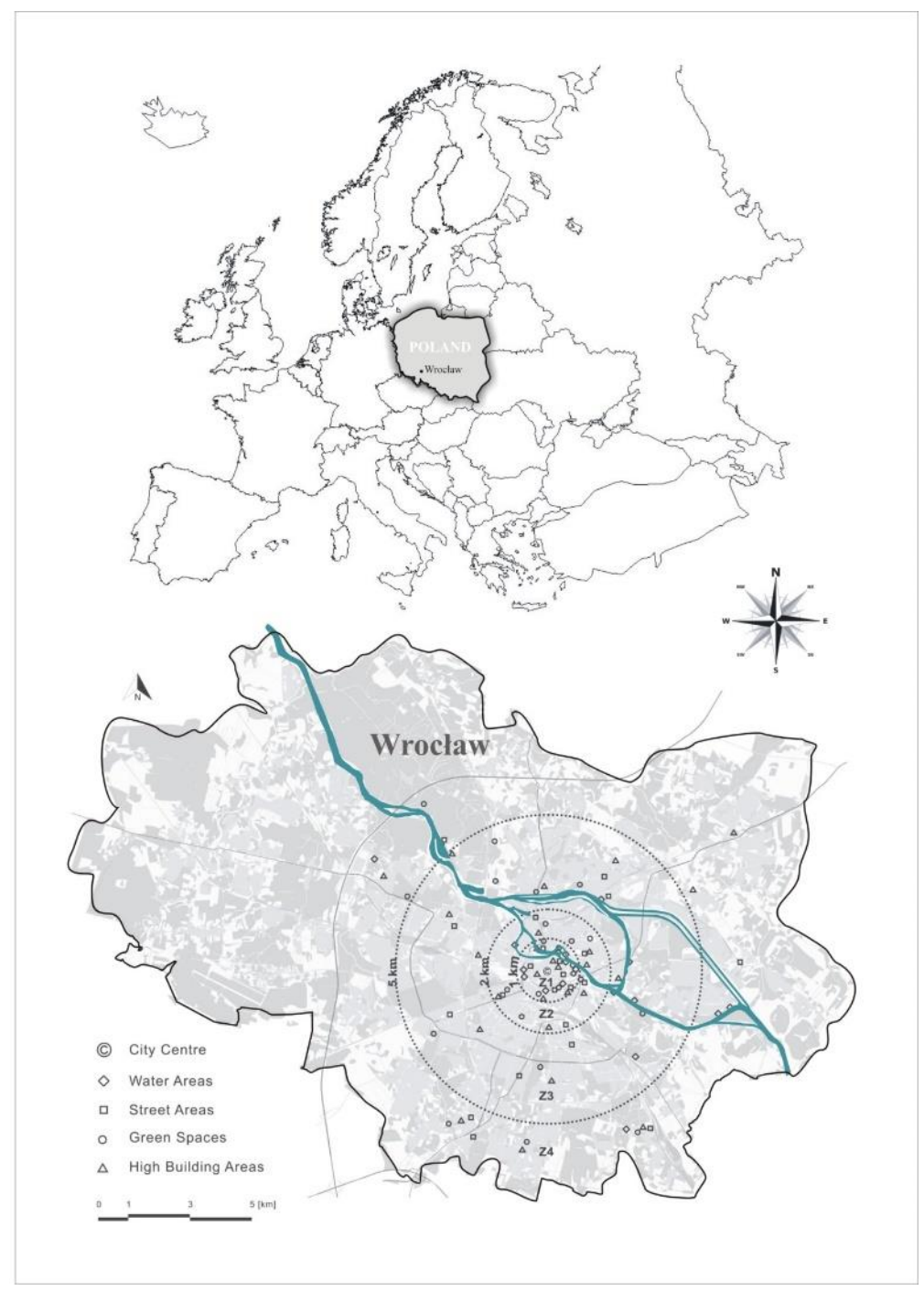

Figure 1. Localization of the research area and distribution of research facilities in Wrocław.

In the year 2017, from March to September, the mean monthly air temperature values for each month were higher than the mean air temperature value for the years 1951-2017 (Figure 2a). In the summer months, from June to July, these values were even $7{ }^{\circ} \mathrm{C}$ higher. On the other hand, November, December and January were characterized by lower average air temperature values compared to the multiannual period average.

In April and July 2017, monthly rainfall totals were much higher than the average values of the compared multiannual period (Figure 2b). Moreover, higher precipitation has been documented in September and October. On the other hand, lower rainfall totals were recorded in May; they were more than three times lower in comparison (approx. $18 \mathrm{~mm}$ ) than the average value of the 1951-2017 period $(60 \mathrm{~mm})$. In the summer months, except for July, lower rainfall was recorded compared to the multiannual period average. Whereas, in March and February the rainfall was close to the mean values in terms of quantity. 
a.

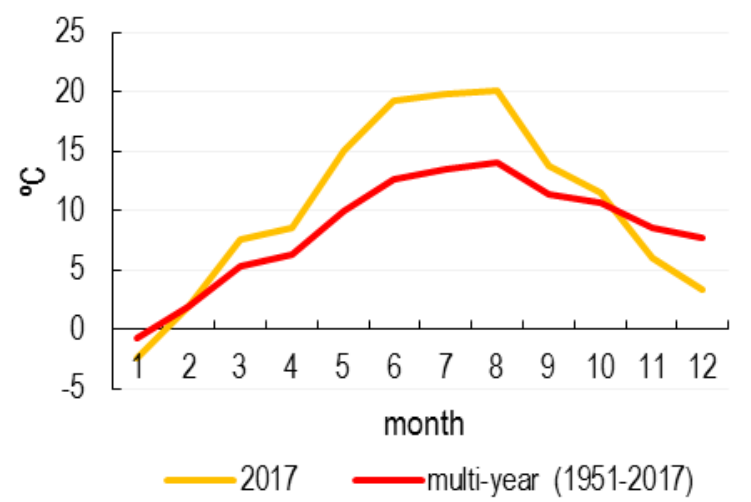

b.

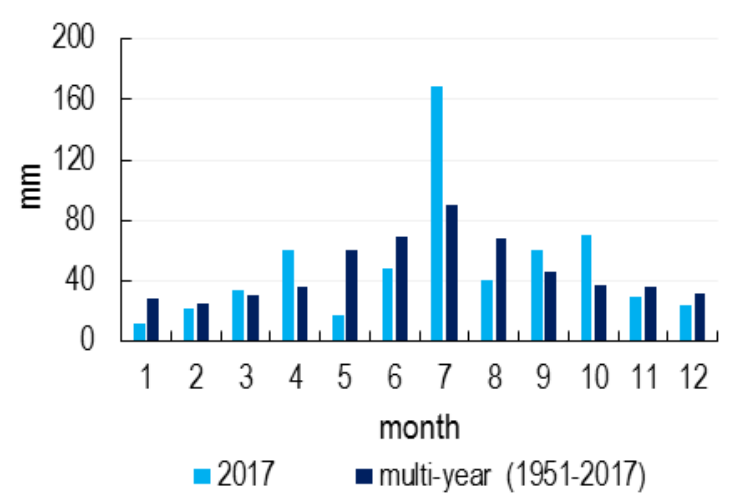

Figure 2. The median monthly air temperature (a) and monthly total precipitation (b) in Wrocław in 2017 and the multiannual period 1951-2017 (based on [49]).

The research area covered the entire city of Wrocław. In order to best capture the impact of the distance from the city center on the rate of changes of individual phenophases, 3 rays were designated (the pillory in the city center in Wrocław, $51^{\circ} 06^{\prime} 34.1^{\prime \prime} \mathrm{N} 17^{\circ} 01^{\prime} 57.7^{\prime \prime} \mathrm{E}$, was taken as a reference point)—at a distance of $1 \mathrm{~km}(\mathrm{R} 1), 2 \mathrm{~km}$ (R2) and $5 \mathrm{~km}$ (R3). The rays were determined with regard to the structure and type of buildings, green areas and UHI temperature distribution developed for Wrocław by Szymanowski and Kryza [50]. These rays were determined in such a way that the first area covered the strict city center (zone $1-\mathrm{Z1}$ ), the second area was with dense historic quarter buildings (zone 2-Z2) and a third area with looser buildings and larger green areas (zone 3-Z3), which separated the zone with the lowest degree of development, with predominantly green areas (zone $4-\mathrm{Z} 4$ ).

\subsection{Research Objects}

The horse chestnut (Aesculus hippocastanum L.), brought to Europe in the 16th century, is one of the most popular species used in urban areas [51]. It has been the subject of observation in many phenology-based studies [6,52-60]. The horse chestnut was chosen for our research as it is a species that occurs frequently in Wrocław, its morphology allows for a precise definition of phenological phases and it is of great environmental and aesthetic importance for the city and additionally, it is characterized by early phenology.

A total of 92 objects were selected for observation (Figure 1)—including 24 located in the central area-zone 1 (Z1), 21 objects between 1 and $2 \mathrm{~km}$ from the center (Z2), 24 facilities in the area from $2-5 \mathrm{~km}(\mathrm{Z3})$ and 22 objects located more than $5 \mathrm{~km}$ from the designated center (Z4). Moreover, when selecting the objects, the form of land cover on which the tested object is located was taken into account, distinguished as follows: green areas, high-rise areas (multi-family buildings with at least 4 storeys were assumed to be high-rise buildings) and areas near communication routes and water courses and reservoirs (Table 1) - in determining the forms of land cover, the Urban Atlas was used [61]. All specimens were also selected taking into account their age- - the units selected for the study had circumferences larger than $150 \mathrm{~cm}$ measured at a height of $130 \mathrm{~cm}$ above the ground and were of good phytosanitary condition. 
Table 1. Number of objects selected for observation depending on the distance from the reference point and type of land cover (Based on [61]).

\begin{tabular}{|c|c|c|c|c|c|c|c|}
\hline \multirow{4}{*}{$\begin{array}{l}\text { Land } \\
\text { Cover }\end{array}$} & \multirow{4}{*}{$\begin{array}{l}\text { Urban Atlas } 2006 \\
\text { for Wrocław }\end{array}$} & \multirow{4}{*}{ Abbrev } & \multicolumn{4}{|c|}{ (Zones) } & \multirow{4}{*}{$\begin{array}{l}\text { Number } \\
\text { of Objects }\end{array}$} \\
\hline & & & \multicolumn{4}{|c|}{ Distance from the City Centre (km) } & \\
\hline & & & Z1 & $\mathbf{Z 2}$ & Z3 & $\mathrm{Z4}$ & \\
\hline & & & 0-1 & $1-2$ & $2-5$ & $>5$ & \\
\hline $\begin{array}{l}\text { Green } \\
\text { Spaces }\end{array}$ & Green urban areas & GS & 8 & 6 & 6 & 7 & 27 \\
\hline $\begin{array}{l}\text { Street } \\
\text { Areas }\end{array}$ & $\begin{array}{l}\text { Other roads and } \\
\text { associated land }\end{array}$ & $S$ & 6 & 6 & 8 & 7 & 27 \\
\hline High-rise & $\begin{array}{c}\text { Continuous Urban fabric } \\
\text { (S.L. }>80 \% \text { ) }\end{array}$ & & & & & & \\
\hline $\begin{array}{l}\text { Building } \\
\text { Areas }\end{array}$ & $\begin{array}{c}\text { Discontinuous Dense } \\
\text { Urban Fabric (S.L.: } \\
50-80 \%)\end{array}$ & $\mathrm{HB}$ & 7 & 6 & 5 & 5 & 24 \\
\hline \multirow[t]{2}{*}{$\begin{array}{l}\text { Water } \\
\text { Areas }\end{array}$} & Water & W & 3 & 3 & 5 & 3 & 14 \\
\hline & Total: & & 24 & 21 & 24 & 22 & 92 \\
\hline
\end{tabular}

\subsection{Field Observations}

Field observations were carried out weekly from 1 March 2017 to the end of November, 2017. In order for the assessment process to be objective, the assessment was made by one person on the basis of photographic documentation collected in the field, which included a photograph of the silhouette of the entire tree and details such as buds, leaves, inflorescences, fruits. We have attached an observation sheet as Supplementary Material (Table S1).

The phenological observations were based on $\mathrm{BBCH}$ (Biologische Bundesantalt, Bundessortenamt and Chemische Industrie) code after Finn et al. [62]. The BBCH scale has been applied so far in phenological observations of non-cultivated woody plant species Babálová et al. [63] in the studies on small-leaved linden, hawthorn, common hazel, blackthorn, by Lukasová et al. [64] examining the common beech or by Stratópoulos at al. [65]. A uniform method of presentation and determination of individual phenological phases was adopted, as specified in Table 2. For the purpose of our research, like in Delgado at al. [66] or Cosmulescu and Scrieciu [67], the BBCH scale has been modified-it has been extended to four new phases marked with an asterisk in Table 2.

Table 2. Division and description of phenophases (based on $\mathrm{BBCH}$ code).

\begin{tabular}{|c|c|c|c|}
\hline $\begin{array}{c}\text { No. of } \\
\text { Phenological } \\
\text { Phase }\end{array}$ & $\begin{array}{c}\text { BBCH } \\
\text { Code }\end{array}$ & Phenological Phase & ВBCH Code Description \\
\hline $\mathrm{Ph} 0$ & BBCH 00 & Leaf buds closed & Buds closed and covered by scales \\
\hline Ph1 & BBCH 07 & $\begin{array}{c}\text { The beginning of the opening of leaf } \\
\text { buds }\end{array}$ & $\begin{array}{c}\text { Beginning of sprouting or bud } \\
\text { breaking }\end{array}$ \\
\hline $\mathrm{Ph} 2$ & $\mathrm{BBCH} 11$ & $\begin{array}{c}\text { The beginning of spreading the leaf } \\
\text { blades }\end{array}$ & First leaves unfolded \\
\hline $\mathrm{Ph} 3$ & BBCH 19 & Full foliation & Leaf expansion complete \\
\hline $\mathrm{Ph} 4$ & ВBCH 93 & The beginning of leaf fall & Beginning of leaf fall \\
\hline Ph5 & ВBCH 97 & The end of leaf fall & End of leaf fall \\
\hline Ph6 & ВBCH 511 * & The appearance of the inflorescence & $\begin{array}{c}\text { Undeveloped inflorescences are } \\
\text { noticeable }\end{array}$ \\
\hline $\mathrm{Ph} 7$ & BBCH $512 *$ & $\begin{array}{l}\text { The full appearance of } \\
\text { the inflorescence }\end{array}$ & $\begin{array}{c}\text { Fully developed inflorescences are } \\
\text { noticeable }\end{array}$ \\
\hline
\end{tabular}


Table 2. Cont.

\begin{tabular}{|c|c|c|c|}
\hline $\begin{array}{c}\text { No. of } \\
\text { Phenological } \\
\text { Phase }\end{array}$ & $\begin{array}{l}\text { BBCH } \\
\text { Code }\end{array}$ & Phenological Phase & ВВСH Code Description \\
\hline Ph8 & ВBCH 62 & The beginning of flowering & $20 \%$ flowers open \\
\hline Ph9 & $\mathrm{BBCH} 652 *$ & Full flowering & above $70 \%$ of flowers open \\
\hline Ph10 & ВBCH 671 * & The flowering finishing & $50 \%$ of petalas fallen or dry \\
\hline Ph11 & BBCH 69 & The end of flowering & Fruit are visible \\
\hline Ph12 & ВBCH 79 & Full ripening of fruit & $80 \%$ of fruits have reached final size \\
\hline Ph14/13 & ВBCH 89 & The end of fruit ripening & fruits fully ripe \\
\hline
\end{tabular}

\subsection{Data Analysis}

The study assessed the average duration of individual phenological phases along with the variability characteristics for leafing, flowering and fruiting in relation to the designated zones and classified forms of land cover based on mean value $(\bar{x})$ and standard deviation $( \pm$ SD) in individual weeks of the year and Julian days.

Moreover, length estimates were performed for the vegetative phases of phenological development duration of individual phases in relation to each other. This length was determined based on the differences between the averaged dates of the observed phases of vegetative development.

In order to verify the statistical significance in relation to comparable groups of trees growing in the designated zones, the $t$-Student test was performed at the level of $p<0.05$.

For the leafing and flowering phases (Ph1-Ph11), the frequency of the occurrence of phases in individual weeks of the year was analyzed in relation to the designated zones and classified land use methods.

\section{Results}

\subsection{Influence of Distance from the Centre on Phenological Development}

The results obtained on the basis of the average time of occurrence of phenological phases for the adopted zones showed that in 2017, the beginning of vegetation was observed faster in the city center than on its periphery (Table 3). The growing season in the city center also lasted longer, on average from mid-12 weeks (i.e., 4th week of March) to the middle of the 45th week of the year (i.e., 2nd week of November), while on the periphery of the city, from the middle of the 13th week (i.e., 1st week of April) to the middle of the 44th week of the year (i.e., 1st week of November).

The phenological phases "The beginning of the opening of leaf buds " $\mathrm{BBCH} 07)$ and "The beginning of spreading the leaf blades" (BBCH 11) were first observed in trees growing in zone Z1 (Table 3). Compared with trees growing in other areas, this difference was approximately one week, occurring in the final third of March. The "Full foliation" (BBCH 19) of trees growing in zones Z1 and $\mathrm{Z} 2$ occurred about 1 week earlier than in trees growing in zones Z3 and Z4. The Ph3 phase for trees growing at a distance of $2-5 \mathrm{~km}$ showed the greatest variability, over 1 week, while trees growing in the center showed almost two times less variability. The "The beginning of leaf fall" (BBCH 93) was characterized by the greatest variability among all vegetative phases, from 2 to even 4 weeks in individual zones. The lowest variability was recorded in the area located more than $5 \mathrm{~km}$ from the center, that is, in zone Z4. The highest variability was documented in zones Z1 and Z3. The average time of "end of leaf fall" (Ph5) occurred at a similar time in all zones. The most noticeable differences were observed between trees growing in zones $\mathrm{Z1}$ and $\mathrm{Z2}$, in which the variability of this phase was smaller compared to trees growing in zones $\mathrm{Z} 3$ and $\mathrm{Z} 4$. 
Table 3. Average onset $(\bar{x})$ date and standard deviation (SD) of occurrence of individual phenological phases depending on the distance from the city center [in weeks and Julian days].

\begin{tabular}{|c|c|c|c|c|c|c|}
\hline \multirow{2}{*}{$\begin{array}{c}\text { No. of } \\
\text { Phenological Phase }\end{array}$} & \multirow{2}{*}{$\begin{array}{l}\text { BBCH } \\
\text { Code }\end{array}$} & \multicolumn{5}{|c|}{ Zone } \\
\hline & & & $\mathrm{Z1}$ & $\mathbf{Z 2}$ & $\mathbf{Z 3}$ & $\mathrm{Z4}$ \\
\hline \multicolumn{7}{|c|}{ Leaves $(\bar{x} \pm \mathrm{SD})$} \\
\hline Ph1 & ВBCH 07 & $\begin{array}{l}\text { J. days } \\
\text { week }\end{array}$ & $\begin{array}{c}86 \pm 3 \\
12.5 \pm 0.5\end{array}$ & $\begin{array}{c}87 \pm 5 \\
12.5 \pm 0.7\end{array}$ & $\begin{array}{c}89 \pm 5 \\
13.0 \pm 0.7\end{array}$ & $\begin{array}{c}91 \pm 7 \\
13.5 \pm 0.9\end{array}$ \\
\hline $\mathrm{Ph} 2$ & ВBCH 11 & $\begin{array}{l}\text { j. days } \\
\text { week }\end{array}$ & $\begin{array}{c}94 \pm 5 \\
13.6 \pm 0.6\end{array}$ & $\begin{array}{c}95 \pm 5 \\
13.9 \pm 0.5\end{array}$ & $\begin{array}{c}99 \pm 6 \\
14.1 \pm 0.7\end{array}$ & $\begin{array}{c}100 \pm 4 \\
14.2 \pm 0.5\end{array}$ \\
\hline $\mathrm{Ph} 3$ & ВBCH 19 & $\begin{array}{l}\text { J. days } \\
\text { week }\end{array}$ & $\begin{array}{c}119 \pm 5 \\
16.8 \pm 0.7\end{array}$ & $\begin{array}{c}119 \pm 7 \\
16.6 \pm 0.9\end{array}$ & $\begin{array}{c}122 \pm 9 \\
17.5 \pm 1.3\end{array}$ & $\begin{array}{c}124 \pm 6 \\
17.6 \pm 0.9\end{array}$ \\
\hline $\mathrm{Ph} 4$ & ВВСН 93 & $\begin{array}{l}\text { J. days } \\
\text { week }\end{array}$ & $\begin{array}{c}264 \pm 24 \\
38.0 \pm 3.4\end{array}$ & $\begin{array}{c}261 \pm 20 \\
37.7 \pm 2.8\end{array}$ & $\begin{array}{c}263 \pm 28 \\
37.8 \pm 3.8\end{array}$ & $\begin{array}{c}262 \pm 17 \\
38.0 \pm 2.3\end{array}$ \\
\hline Ph5 & ВВСН 97 & $\begin{array}{l}\text { J. days } \\
\text { week }\end{array}$ & $\begin{array}{l}317 \pm 9.8 \\
45.5 \pm 1.4\end{array}$ & $\begin{array}{c}311 \pm 13 \\
44.6 \pm 1.8\end{array}$ & $\begin{array}{c}312 \pm 12 \\
44.7 \pm 1.8\end{array}$ & $\begin{array}{c}311 \pm 8 \\
44.6 \pm 1.1\end{array}$ \\
\hline \multicolumn{7}{|c|}{ Flowers and Fruits $(\bar{x} \pm$ SD) } \\
\hline Ph6 & ВBCH 511 & $\begin{array}{l}\text { j. days } \\
\text { week }\end{array}$ & $\begin{array}{c}99 \pm 5 \\
14.2 \pm 0.7\end{array}$ & $\begin{array}{c}99 \pm 6 \\
14.1 \pm 0.8\end{array}$ & $\begin{array}{c}102 \pm 6 \\
14.6 \pm 0.9\end{array}$ & $\begin{array}{c}104 \pm 5 \\
14.0 \pm 0.7\end{array}$ \\
\hline $\mathrm{Ph} 7$ & BBCH 512 & $\begin{array}{l}\text { J. days } \\
\text { week }\end{array}$ & $\begin{array}{c}109 \pm 6 \\
15.7 \pm 0.8\end{array}$ & $\begin{array}{c}111 \pm 7 \\
15.8 \pm 0.9\end{array}$ & $\begin{array}{c}113 \pm 6 \\
16.2 \pm 0.8\end{array}$ & $\begin{array}{c}116 \pm 5 \\
16.0 \pm 0.7\end{array}$ \\
\hline $\mathrm{Ph} 8$ & ВBCH 62 & $\begin{array}{l}\text { J. days } \\
\text { week }\end{array}$ & $\begin{array}{c}119 \pm 6 \\
16.9 \pm 0.8\end{array}$ & $\begin{array}{c}120 \pm 7 \\
17.1 \pm 1.0\end{array}$ & $\begin{array}{c}124 \pm 7 \\
17.5 \pm 1.0\end{array}$ & $\begin{array}{c}126 \pm 4 \\
18.0 \pm 0.7\end{array}$ \\
\hline $\mathrm{Ph} 9$ & ВBCH 652 & $\begin{array}{l}\text { J. days } \\
\text { week }\end{array}$ & $\begin{array}{c}131 \pm 4 \\
18.7 \pm 0.6\end{array}$ & $\begin{array}{c}133 \pm 5 \\
18.9 \pm 0.8\end{array}$ & $\begin{array}{c}137 \pm 5 \\
19.5 \pm 0.7\end{array}$ & $\begin{array}{c}138 \pm 4 \\
19.0 \pm 0.5\end{array}$ \\
\hline Ph10 & ВBCH 671 & $\begin{array}{c}\text { J. days } \\
\text { week }\end{array}$ & $\begin{array}{c}143 \pm 4 \\
20.4 \pm 0.9\end{array}$ & $\begin{array}{c}144 \pm 5 \\
20.7 \pm 0.8\end{array}$ & $\begin{array}{c}146 \pm 5 \\
20.9 \pm 0.7\end{array}$ & $\begin{array}{c}145 \pm 5 \\
20.0 \pm 0.7\end{array}$ \\
\hline $\mathrm{Ph} 11$ & ВBCH 69 & $\begin{array}{l}\text { J. days } \\
\text { week }\end{array}$ & $\begin{array}{c}157 \pm 6 \\
22.3 \pm 0.7\end{array}$ & $\begin{array}{l}158 \pm 10 \\
22.5 \pm 1.3\end{array}$ & $\begin{array}{c}157 \pm 7 \\
22.4 \pm 0.9\end{array}$ & $\begin{array}{c}157 \pm 7 \\
22.0 \pm 0.9\end{array}$ \\
\hline $\mathrm{Ph} 12$ & BBCH 79 & $\begin{array}{l}\text { J. days } \\
\text { week }\end{array}$ & $\begin{array}{c}193 \pm 9 \\
27.8 \pm 1.3\end{array}$ & $\begin{array}{c}200 \pm 13 \\
28.7 \pm 1.8\end{array}$ & $\begin{array}{c}206 \pm 17 \\
29.7 \pm 2.5\end{array}$ & $\begin{array}{c}205 \pm 16 \\
29.6 \pm 2.5\end{array}$ \\
\hline $\mathrm{Ph} 13$ & BBCH 89 & $\begin{array}{l}\text { J. days } \\
\text { week }\end{array}$ & $\begin{array}{c}240 \pm 22 \\
35.0 \pm 3.1\end{array}$ & $\begin{array}{c}241 \pm 18 \\
34.6 \pm 2.6\end{array}$ & $\begin{array}{c}244 \pm 15 \\
35.1 \pm 2.4\end{array}$ & $\begin{array}{c}245 \pm 9 \\
35.4 \pm 1.5\end{array}$ \\
\hline
\end{tabular}

"The appearance of the inflorescence" (BBCH 511*) was observed the earliest in zones Z1 and Z2, at the beginning of the 14 th week of the year (Table 3). The "The beginning of flowering "(BBCH 62) occurred on average in the 17th week of the year for trees growing in the city center in zones Z1 and Z2 and a week later for trees growing in zone Z4. The "Full flowering" (BBCH 671*) were first recorded on trees within $1 \mathrm{~km}$ (zone Z1), while in the remaining zones, the appearance of this phase was similar in time. "The end of flowering "(BBCH 69) was recorded simultaneously on all trees, regardless of the distance from the center of Wrocław.

The appearance of the phenological phases concerning fruiting in all trees was similar, regardless of the designated zone (Table 3). These phases were characterized by the greatest variability among all phenological phases, especially "Full ripening of fruit" (BBCH 79) and "The end of fruit ripening" (BBCH 89).

Table 4 shows the duration of the individual vegetative phases on the basis of the difference between the averaged dates of phase appearance. The greatest differences in the length of the growing season of horse chestnut, from the cracking of leaf buds to the end of leaf fall, were documented between trees growing in zone Z1 and trees in zone Z4-a difference of almost 2 weeks. However, 
the difference between trees growing in zones $\mathrm{Z} 1$ and $\mathrm{Z} 2$ is about 1 week, between zones $\mathrm{Z} 2$ and $\mathrm{Z3}$, only half a week and for Z2 and Z4, it is again 1 week.

Table 4. Duration of the vegetative phases (Ph1-Ph5) in 2017, for trees in individual zones (Z) (in weeks).

\begin{tabular}{|c|c|c|c|c|c|c|c|c|c|c|c|c|c|}
\hline \multirow{6}{*}{ Z1 } & & Ph1 & Ph2 & $\mathrm{Ph} 3$ & $\mathrm{Ph} 4$ & Ph5 & \multirow{6}{*}{ Z3 } & & Ph1 & $\mathrm{Ph} 2$ & Ph3 & Ph4 & Ph5 \\
\hline & Ph1 & & - & - & - & - & & Ph1 & & - & - & - & - \\
\hline & $\mathrm{Ph} 2$ & 1.1 & & - & - & - & & Ph2 & 1.1 & & - & - & - \\
\hline & Ph3 & 4.3 & 3.2 & & - & - & & Ph3 & 4.5 & 3.4 & & - & - \\
\hline & Ph4 & 25.5 & 24.4 & 21.2 & & - & & Ph4 & 24.8 & 23.7 & 20.3 & & - \\
\hline & Ph5 & 33.0 & 31.9 & 28.7 & 7.5 & & & Ph5 & 31.7 & 30.6 & 27.2 & 6.9 & \\
\hline \multirow{6}{*}{$\mathrm{Z} 2$} & & Ph1 & Ph2 & $\mathrm{Ph} 3$ & $\mathrm{Ph} 4$ & $\mathrm{Ph} 5$ & \multirow{6}{*}{$\mathrm{Z4}$} & & Ph1 & $\mathrm{Ph} 2$ & Ph3 & $\mathrm{Ph} 4$ & Ph5 \\
\hline & Ph1 & & - & - & - & - & & Ph1 & & - & - & - & - \\
\hline & Ph2 & 1.4 & & - & - & - & & Ph2 & 0.7 & & - & - & - \\
\hline & Ph3 & 4.1 & 2.7 & & - & - & & Ph3 & 4.1 & 3.4 & & - & - \\
\hline & Ph4 & 25.2 & 23.8 & 21.1 & & - & & Ph4 & 24.5 & 23.8 & 20.4 & & - \\
\hline & Ph5 & 32.1 & 30.7 & 28.0 & 8.9 & & & Ph5 & 31.1 & 30.4 & 27.0 & 6.6 & \\
\hline
\end{tabular}

On the basis of the $t$-Student test (Table 5), it was shown that the differences in the course of phenological phases between groups of trees distant from each other between zones Z1 and Z3, Z1 and Z4 as well as Z2 and Z4 were statistically significant. However, there were no statistically significant differences between the groups of trees growing in neighboring zones such as $Z 1$ and $Z 2, Z 2$ and $Z 3$ and Z3 and Z4. The analysis of the fruiting phases showed no statistical significance in relation to comparable groups. The Ph5 phase (BBCH 97-The end of leaf fall) was statistically significant only between trees growing in zones Z1 and Z3 and Z1 and Z4. There were no statistically significant differences for the leaf fall phases.

On the basis of the frequency analysis, it was shown that with increasing distance from the city center, the frequency of particular phases decreases and their duration increases at the same time (Figure 3). This regularity was especially noticeable for the initial phases Ph1 (BBCH 07) and Ph2 (BBCH 11). In trees growing in zones $\mathrm{Z3}$ and $\mathrm{Z4}$, a delay in individual phenological phases was observed more often. The Ph4 phase (BBCH 93) was characterized by high variability, especially up to $2 \mathrm{~km}$ from the city center, where in approx. $20 \%$ of horse chestnut trees, the leaves remained on the tree longer. In the case of the Ph5 phase (BBCH 97), trees growing in zone Z1 maintained their leaves longer than trees in other zones. The total defoliation of trees in the Z1 zone is initially more dynamic (individual observations in the following weeks) compared to trees growing more than $1 \mathrm{~km}$ from the city center. In trees growing in the $\mathrm{Z} 4$ zone, the $\mathrm{Ph} 4$ phase (BBCH 93) was recorded in more than $20 \%$ over 34 weeks, while in the center, this phase was observed only in $8 \%$ of trees. In 43 weeks, within a radius of $1 \mathrm{~km}$ from the center, only about $8 \%$ of trees without leaves were recorded, while in further zones it was over $40 \%$ in $\mathrm{Z} 2$ and over $30 \%$ in $\mathrm{Z3}$ and $\mathrm{Z} 4$. 
Table 5. The values of Student's $t$-test for phenological phases $(\mathrm{Ph})$ of leaves and flowers between trees, growing in individual zones (Z1-Z4) of the city.

\begin{tabular}{|c|c|c|c|c|c|c|c|c|c|c|c|}
\hline \multicolumn{12}{|c|}{ Leaves } \\
\hline \multicolumn{2}{|c|}{ Ph0 (BBCH 00) } & \multicolumn{2}{|c|}{ Ph1 (BBCH 07) } & \multicolumn{2}{|c|}{ Ph2 (BBCH 11) } & \multicolumn{2}{|c|}{ Ph3 (BBCH 19) } & \multicolumn{2}{|c|}{ Ph4 (BBCH 93) } & \multicolumn{2}{|c|}{ Ph5 (BBCH 97) } \\
\hline Zone & $t$ & Zone & $t$ & Zone & $t$ & Zone & $t$ & Zone & $t$ & Zone & $t$ \\
\hline Z1:Z2 & - & $\mathrm{Z1:Z2}$ & - & Z1:Z2 & - & $\mathrm{Z1:Z2}$ & - & $\mathrm{Z1:Z2}$ & - & $\mathrm{Z1:Z2}$ & - \\
\hline $\mathrm{Z} 2: \mathrm{Z3}$ & - & Z2:Z3 & $-2.07 * *$ & $\mathrm{Z2:Z3}$ & - & $\mathrm{Z2:Z3}$ & - & Z2:Z3 & - & $\mathrm{Z2:Z3}$ & - \\
\hline Z3:Z4 & - & Z3:Z4 & - & Z3:Z4 & - & $\mathrm{Z3:Z4}$ & - & Z3:Z4 & - & $\mathrm{Z3}: \mathrm{Z4}$ & - \\
\hline Z1:Z3 & - & Z1:Z3 & $-2.6^{*}$ & Z1:Z3 & $-2.55^{*}$ & $\mathrm{Z1:Z3}$ & $-2.03^{* *}$ & $\mathrm{Z1:Z3}$ & - & $\mathrm{Z1:Z3}$ & $2.04 * *$ \\
\hline $\mathrm{Z1:Z4}$ & - & Z1:Z4 & $-3.28 *$ & Z1:Z4 & $-3.72 *$ & Z1:Z4 & $-3.26^{*}$ & $\mathrm{Z1:Z4}$ & - & $\mathrm{Z1:Z4}$ & $2.6^{* * *}$ \\
\hline $\mathrm{Z2:Z4}$ & - & $\mathrm{Z2:Z4}$ & $-2.78 *$ & $\mathrm{Z2:Z4}$ & $-2.13^{* *}$ & $\mathrm{Z2:Z4}$ & $-2.35^{* *}$ & $\mathrm{Z2:Z4}$ & - & $\mathrm{Z2:Z4}$ & - \\
\hline \multicolumn{12}{|c|}{ Flowers } \\
\hline \multicolumn{2}{|c|}{ Ph6 (BBCH 511) } & \multicolumn{2}{|c|}{ Ph7 (BBCH 512) } & \multicolumn{2}{|c|}{ Ph8 (BBCH 62) } & \multicolumn{2}{|c|}{ Ph9 (BBCH 652) } & \multicolumn{2}{|c|}{ Ph10 (BBCH 671) } & \multicolumn{2}{|c|}{ Ph11 (BCCH 69) } \\
\hline Zone & $t$ & Zone & $t$ & Zone & $t$ & Zone & $t$ & Zone & $t$ & Zone & $t$ \\
\hline $\mathrm{Z1:Z2}$ & - & $\mathrm{Z1:Z2}$ & - & $\mathrm{Z1:Z2}$ & - & $\mathrm{Z1:Z2}$ & - & $\mathrm{Z1:Z2}$ & - & $\mathrm{Z1:Z2}$ & - \\
\hline $\mathrm{Z} 2: \mathrm{Z3}$ & - & $\mathrm{Z2:Z3}$ & - & $\mathrm{Z2:Z3}$ & - & $\mathrm{Z2:Z3}$ & $-2.87 *$ & $\mathrm{Z2:Z3}$ & - & $\mathrm{Z2:Z3}$ & - \\
\hline Z3:Z4 & - & Z3:Z4 & - & Z3:Z4 & - & Z3:Z4 & - & Z3:Z4 & - & $\mathrm{Z3}: \mathrm{Z4}$ & - \\
\hline Z1:Z3 & - & Z1:Z3 & $-2.21 * *$ & Z1:Z3 & $-2.62 *$ & Z1:Z3 & $-4.26^{*}$ & Z1:Z3 & - & Z1:Z3 & - \\
\hline $\mathrm{Z1:Z4}$ & $-3.24 *$ & $\mathrm{Z1:Z4}$ & $-3.73 *$ & $\mathrm{Z1:Z4}$ & $-5.14 *$ & $\mathrm{Z1:Z4}$ & $-6.17 *$ & $\mathrm{Z1:Z4}$ & - & $\mathrm{Z1:Z4}$ & - \\
\hline $\mathrm{Z} 2: \mathrm{Z4}$ & $-3.14^{*}$ & $\mathrm{Z} 2: \mathrm{Z4}$ & $-2.76^{* * *}$ & Z2:Z4 & $-3.36^{*}$ & Z2:Z4 & $-4.33 *$ & Z2:Z4 & - & Z2:Z4 & - \\
\hline
\end{tabular}

t.-t-student, $p=0,01^{*} ; p<0,05^{* * ;} ;<0,1^{* * *}$ 

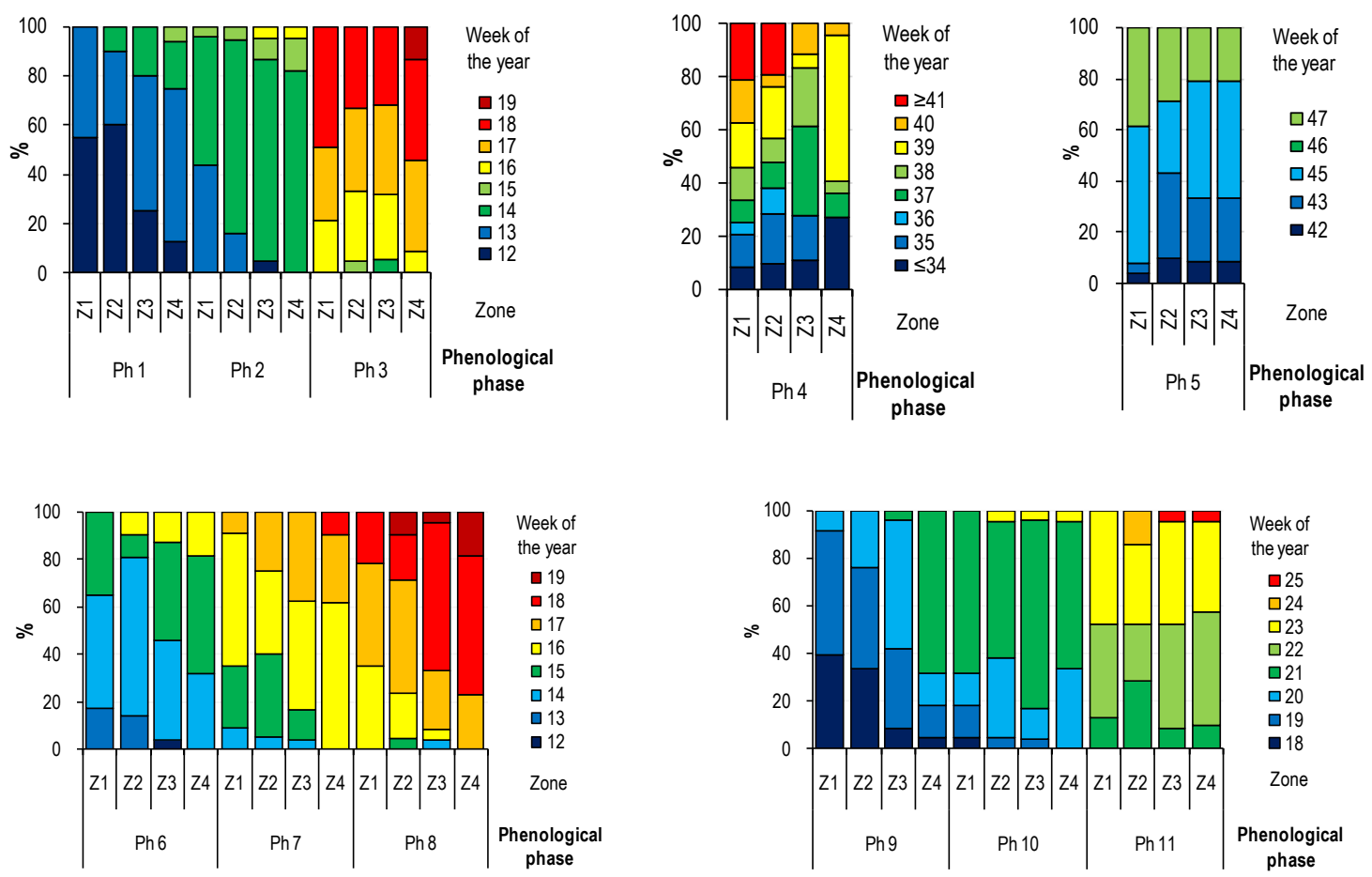

Figure 3. The frequency of occurrence of selected phenological phases (Ph1-Ph11) depending on the distance from the city center (BBCH code see Table 3$)$.

The assessment of the frequency of the generative development phases from $\mathrm{Ph} 6$ to $\mathrm{Ph} 9 \mathrm{BBCH}$ : $511^{*}, 512^{*}, 62,652^{*}$ ) showed that they took place first in the city center and with the increasing of the distance from the city center, were observed later. The full flowering of the horse chestnut tree began in the 18th week of the year. At that time, $39 \%$ and $33 \%$ of the observed specimens flourished in $\mathrm{Z} 1$ and $\mathrm{Z} 2$, respectively, while only $8.3 \%$ and $4.5 \%$ flourished in zones Z3 and Z4. In the case of phases Ph10 (BBCH 671*) and Ph11 (BBCH 69), this regularity was not so clear. On the other hand, it was noticeable that within the $\mathrm{Z} 3$ and $\mathrm{Z} 4$ zones, trees whose phenological phases were delayed in relation to trees growing in the central parts of the city were noted more often.

\subsection{The Impact of Land Use on the Pace of Phenological Development}

Table 6 shows the results of analysis of the dates of occurrence of the individual phenological phases depending on the form of cover where the observed trees grow. The average period of the initial appearance of phenological phases Ph1 to Ph3 (BBCH: 07, 11, 19) were similar, irrespective of the form of coverage in the area within which they were observed. Particularly noteworthy is phase $\mathrm{Ph} 4$ (BBCH 93), which is characterized by a considerable variability, ranging from 2 to almost four weeks. depending on the form of land cover. The phenophases of trees growing in green areas and by reservoirs and watercourses were characterized by a lower variability in their frequency compared to the variability of the phenophases of trees growing in the vicinity of high-rise areas and along communication routes, for which this variability was more than one week. Moreover, in trees growing along the streets, the beginning of leaf fall occurred 2 weeks earlier than in trees growing near reservoirs and watercourses and with high-rise buildings. Even greater differences were noted in relation to trees growing in green areas-over 3 weeks. In the case of flowering, no clear differences were noted between the phenophases of trees growing depending on the form of land cover, within limits and the same was true for their variability. 
Table 6. Average date $(x)$ and standard deviation (SD) of the occurrence of individual phenological phases depending on the form of land cover [in Julian days and weeks].

\begin{tabular}{|c|c|c|c|c|c|c|}
\hline \multirow{2}{*}{$\begin{array}{c}\text { No. of } \\
\text { Phenological } \\
\text { Phase }\end{array}$} & \multirow[b]{2}{*}{$\begin{array}{c}\text { ВВСH } \\
\text { Code }\end{array}$} & \multicolumn{5}{|c|}{ Zone } \\
\hline & & & $\begin{array}{l}\text { Green } \\
\text { Spaces }\end{array}$ & $\begin{array}{l}\text { Street } \\
\text { Areas }\end{array}$ & $\begin{array}{c}\text { High-Rise } \\
\text { Building } \\
\text { Areas }\end{array}$ & $\begin{array}{l}\text { Water } \\
\text { Areas }\end{array}$ \\
\hline \multicolumn{7}{|c|}{ Leaves $(\bar{x} \pm \mathrm{SD})$} \\
\hline \multirow{2}{*}{ Ph1 } & \multirow{2}{*}{ ВBCH 07} & j. days & $86 \pm 5$ & $89 \pm 6$ & $87 \pm 5$ & $89 \pm 7$ \\
\hline & & week & $12.7 \pm 0.7$ & $13.0 \pm 0.8$ & $12.6 \pm 0.7$ & $12.8 \pm 0.9$ \\
\hline \multirow{2}{*}{$\mathrm{Ph} 2$} & \multirow{2}{*}{ ВBCH 11} & J. days & $97 \pm 5$ & $97 \pm 5$ & $97 \pm 5$ & $100 \pm 4$ \\
\hline & & week & $13.9 \pm 0.7$ & $14.0 \pm 0.6$ & $13.8 \pm 0.6$ & $14.1 \pm 0.5$ \\
\hline \multirow{2}{*}{$\mathrm{Ph} 3$} & \multirow{2}{*}{ ВBCH 19} & J. days & $121 \pm 8$ & $121 \pm 6$ & $119 \pm 8$ & $122 \pm 6$ \\
\hline & & week & $17.3 \pm 1.1$ & $17.3 \pm 1.0$ & $16.9 \pm 1.4$ & $17.4 \pm 0.9$ \\
\hline \multirow{2}{*}{$\mathrm{Ph} 4$} & \multirow{2}{*}{$\mathrm{BBCH} 93$} & J. days & $271 \pm 17$ & $251 \pm 25$ & $265 \pm 22$ & $265 \pm 19$ \\
\hline & & week & $38.9 \pm 2.3$ & $36.1 \pm 3.6$ & $38.0 \pm 3.1$ & $38.0 \pm 2.6$ \\
\hline \multirow{2}{*}{ Ph5 } & \multirow{2}{*}{ BBCH 97} & J. days & $314 \pm 11$ & $309 \pm 9$ & $317 \pm 10$ & $312 \pm 11$ \\
\hline & & week & $44.9 \pm 1.6$ & $44.3 \pm 1.2$ & $45.4 \pm 1.5$ & $44.9 \pm 1.6$ \\
\hline \multicolumn{7}{|c|}{ Flowers and fruits $(\bar{x} \pm \mathrm{SD})$} \\
\hline \multirow{2}{*}{ Ph6 } & \multirow{2}{*}{ BBCH 511} & j. days & $101 \pm 4,5$ & $101 \pm 6$ & $100 \pm 7$ & $101 \pm 5$ \\
\hline & & week & $14.5 \pm 0.7$ & $14.5 \pm 0.8$ & $14.3 \pm 1.0$ & $14.5 \pm 0.8$ \\
\hline \multirow{2}{*}{ Ph7 } & \multirow{2}{*}{ BBCH 512} & J. days & $111 \pm 6$ & $114 \pm 6$ & $111 \pm 7$ & $113 \pm 7$ \\
\hline & & week & $15.9 \pm 0.7$ & $16.2 \pm 0123.7$ & $15.9 \pm 0.9$ & $16.1 \pm 0.9$ \\
\hline \multirow{2}{*}{$\mathrm{Ph} 8$} & \multirow{2}{*}{ ВBCH 62} & J. days & $121 \pm 7$ & $123 \pm 5$ & $120 \pm 8$ & $126 \pm 6$ \\
\hline & & week & $17.3 \pm 0.9$ & $17.5 \pm 0.7$ & $17.1 \pm 1.1$ & $17.8 \pm 0.9$ \\
\hline \multirow{2}{*}{$\mathrm{Ph} 9$} & \multirow{2}{*}{ BBCH 652} & J. days & $135 \pm 5$ & $135 \pm 5$ & $135 \pm 6$ & $135 \pm 7$ \\
\hline & & week & $19.2 \pm 0.8$ & $19.3 \pm 0.7$ & $19.2 \pm 0.9$ & $19.3 \pm 0.9$ \\
\hline \multirow{2}{*}{ Ph10 } & \multirow{2}{*}{ ВBCH 671} & J. days & $145 \pm 6$ & $147 \pm 5$ & $144 \pm 4$ & $147 \pm 7$ \\
\hline & & week & $20.7 \pm 0.8$ & $20.5 \pm 0.8$ & $20.6 \pm 0.6$ & $21.1 \pm 0.9$ \\
\hline \multirow{2}{*}{ Ph 11} & \multirow{2}{*}{ ВBCH 69} & j. days & $156 \pm 7$ & $157 \pm 6$ & $158 \pm 8$ & $161 \pm 8$ \\
\hline & & week & $22.2 \pm 0.9$ & $22.3 \pm 0.8$ & $22.4 \pm 1.0$ & $22.8 \pm 1.1$ \\
\hline \multirow{2}{*}{ Ph 12} & \multirow{2}{*}{ ВBCH 79} & J. days & $198 \pm 10$ & $202 \pm 15$ & $200 \pm 17$ & $209 \pm 17$ \\
\hline & & week & $28.4 \pm 1.4$ & $29.1 \pm 2.2$ & $28.8 \pm 2.6$ & $30.1 \pm 2.5$ \\
\hline \multirow{2}{*}{$\mathrm{Ph} 13$} & \multirow{2}{*}{ ВBCH 89} & j. days & $238 \pm 19$ & $245 \pm 12$ & $235 \pm 18$ & $257 \pm 10$ \\
\hline & & week & $34.6 \pm 2.6$ & $35.4 \pm 2.0$ & $33.8 \pm 2.7$ & $37.1 \pm 1.3$ \\
\hline
\end{tabular}

The analysis of the duration of phenological phases, taking into account the form of land cover on which the observed specimens grow, showed that trees growing along communication areas have a shorter vegetative period compared to trees growing in other areas (Table 7). This difference ranged from 1 week in comparison to the areas located by the reservoirs and watercourses to almost 2 weeks for trees growing in the vicinity of high-rise buildings. The leaves remained the longest on trees growing in the vicinity of tall buildings, where the vegetation lasted more than 1.5 weeks longer than in the streets. 
Table 7. Duration of vegetative phases (Ph1-Ph5) depending on the form of land cover (in weeks).

\begin{tabular}{|c|c|c|c|c|c|c|c|c|c|c|c|c|c|}
\hline \multirow{6}{*}{$\begin{array}{l}\text { Green } \\
\text { Spaces }\end{array}$} & & Ph1 & Ph2 & Ph3 & Ph4 & Ph5 & \multirow{6}{*}{$\begin{array}{l}\text { Street } \\
\text { Areas }\end{array}$} & & Ph1 & Ph2 & Ph3 & Ph4 & Ph5 \\
\hline & Ph1 & & - & - & - & - & & Ph1 & & - & - & - & - \\
\hline & Ph2 & 1.2 & & - & - & - & & Ph2 & 1.0 & & - & - & - \\
\hline & Ph3 & 4.6 & 3.4 & & - & - & & Ph3 & 4.3 & 3.3 & & - & - \\
\hline & Ph4 & 26.2 & 25.0 & 21.6 & & - & & Ph4 & 23.1 & 22.1 & 18.8 & & - \\
\hline & Ph5 & 32.2 & 31.0 & 27.6 & 6.0 & & & Ph5 & 31.1 & 30.3 & 27.0 & 8.2 & \\
\hline \multirow{6}{*}{$\begin{array}{c}\text { High-rise } \\
\text { Building } \\
\text { Areas }\end{array}$} & & Ph1 & Ph2 & Ph3 & Ph4 & Ph5 & \multirow{6}{*}{$\begin{array}{l}\text { Water } \\
\text { Areas }\end{array}$} & & Ph1 & Ph2 & Ph3 & $\mathrm{Ph} 4$ & Ph5 \\
\hline & Ph1 & & - & - & - & - & & Ph1 & & - & - & - & - \\
\hline & Ph2 & 1.2 & & - & - & - & & Ph2 & 1.3 & & - & - & - \\
\hline & Ph3 & 4.3 & 3.1 & & - & - & & Ph3 & 4.6 & 3.3 & & - & - \\
\hline & $\mathrm{Ph} 4$ & 25.4 & 24.2 & 21.1 & & - & & $\mathrm{Ph} 4$ & 25.2 & 23.9 & 20.6 & & - \\
\hline & Ph5 & 32.8 & 31.6 & 28.5 & 7.4 & & & Ph5 & 32.1 & 30.8 & 27.5 & 6.9 & \\
\hline
\end{tabular}

Ph1-BBCH 07; Ph2-BBCH 11; Ph3-BBCH 19; Ph4-BBCH; Ph5-BBCH. 
Based on the frequency analysis (Figure 4), it was shown that trees growing along communication routes entered the growing season the latest, that is, in the 12th week of the year-during this time, the $\mathrm{Ph} 1$ phase was recorded in only $17 \%$ of specimens. In the same week, it was observed in approx. $50 \%$ of specimens growing in green areas, by water reservoirs and by tall buildings. $\mathrm{Ph} 4$ phase was the earliest observed on trees growing along streets. On the other hand, the longest leaves remained on trees growing in green areas and among tall buildings. Moreover, the $\mathrm{Ph} 8$ phase was observed at the latest on trees growing near water reservoirs and the Ph10 phase most often on trees growing along communication routes.
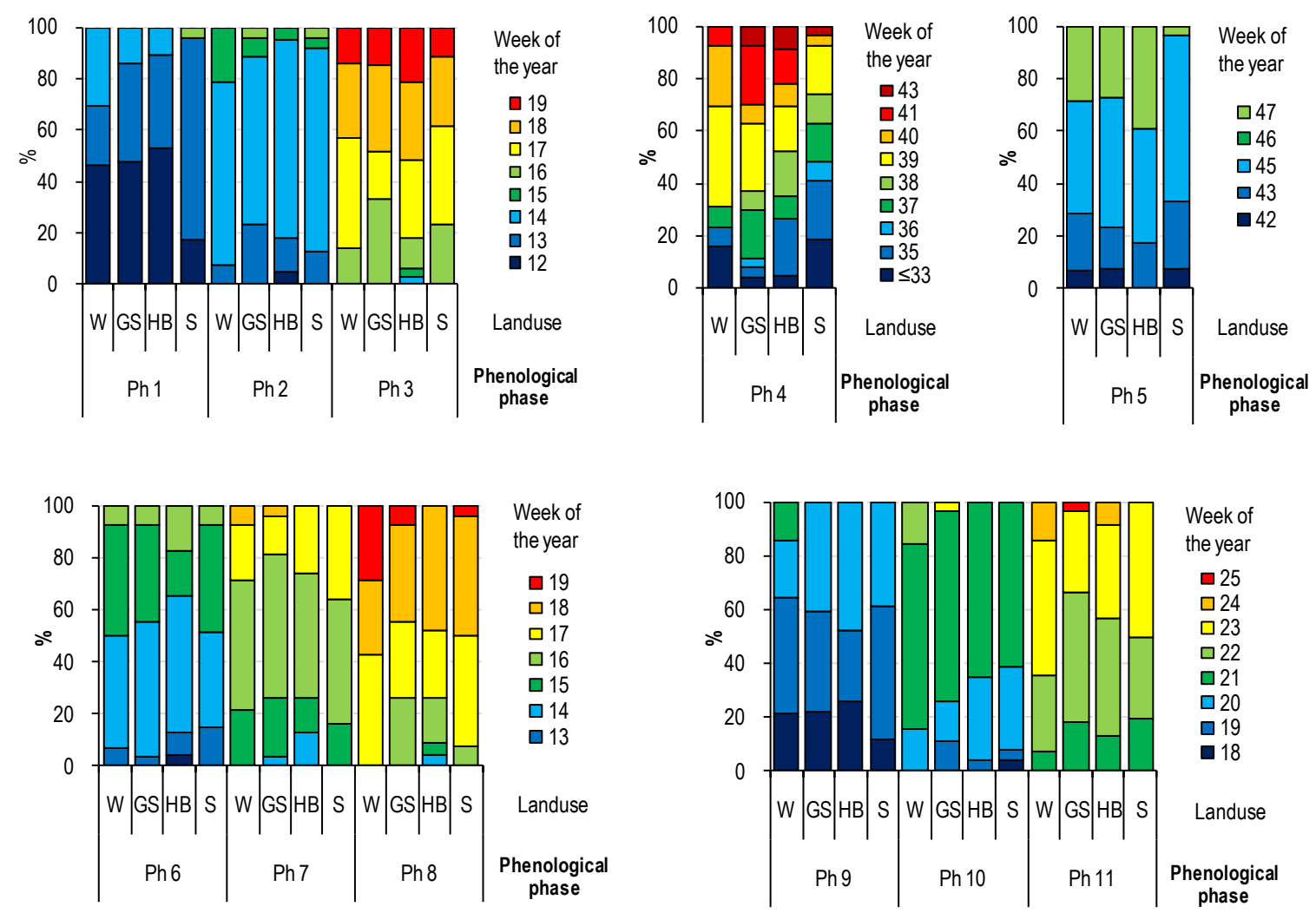

GS-Green Spaces; S-Street Areas; HB-High-rise Building Areas; W-Water Areas

Figure 4. The frequency of occurrence of selected phenological phases (Ph1-Ph11) depending on the type of land use (BBCH code see Table 3).

\subsection{Form of Land Cover and Distance and Their Influence on Phenology}

Based on the averaged dates of the beginning of the phenological phases, it was found that, regardless of the form of land cover, the Ph1 phase was observed at the latest on trees growing in zone Z4 (Table 8). The Ph1 phase, regardless of the zone, was first observed on trees growing near high-rise buildings. It was most clearly visible in the Z4 zone. Similar results were obtained for trees growing in green areas. The Ph1 phase is observed the least in trees growing along communication routes compared with areas of different forms of coverage, especially in zone Z4. Similar results were obtained for trees growing near watercourses and reservoirs, however, less variability of phenophases was observed here. 
Table 8. Average phenological data $(\bar{x})$ and variability $( \pm S D)$ in individual groups of land cover forms. taking into account the distance from the center [in weeks and Julian days].

\begin{tabular}{|c|c|c|c|c|c|c|c|c|c|c|}
\hline \multirow{2}{*}{$\begin{array}{c}\text { No. of Phenological } \\
\text { Phase }\end{array}$} & \multirow{2}{*}{ BBCH Code } & & \multicolumn{4}{|c|}{ Street Areas } & \multicolumn{4}{|c|}{ Green Spaces } \\
\hline & & & $\mathrm{Z1}$ & $\mathrm{Z} 2$ & $\mathrm{Z3}$ & $\mathrm{Z4}$ & $\mathrm{Z1}$ & $\mathbf{Z 2}$ & Z3 & $\mathrm{Z4}$ \\
\hline \multirow{2}{*}{ Ph1 } & \multirow{2}{*}{ ВBCH 07} & j. days & $89 \pm 3$ & $87 \pm 4$ & $89 \pm 1$ & $94 \pm 10$ & $85 \pm 3$ & $86 \pm 4$ & $90 \pm 7$ & $90 \pm 5$ \\
\hline & & week & $12.8 \pm 0.4$ & $12.5 \pm 0.6$ & $13.0 \pm 0.0$ & $13.6 \pm 1.3$ & $12.3 \pm 0.5$ & $12.4 \pm 0.5$ & $13.0 \pm 1.0$ & $13.0 \pm 0.7$ \\
\hline \multirow{2}{*}{$\mathrm{Ph} 2$} & \multirow{2}{*}{ BBCH 11} & j. days & $95 \pm 7$ & $93 \pm 5$ & $98 \pm 1$ & $101 \pm 6$ & $93 \pm 4$ & $96 \pm 4$ & $100 \pm 6$ & $99 \pm 3$ \\
\hline & & week & $13.8 \pm 0.8$ & $13.8 \pm 0.5$ & $14.0 \pm 0.0$ & $14.3 \pm 0.8$ & $13.4 \pm 0.5$ & $13.8 \pm 0.4$ & $14.5 \pm 0.8$ & $14.1 \pm 0.4$ \\
\hline \multirow{2}{*}{$\mathrm{Ph} 3$} & \multirow{2}{*}{ ВBCH 19} & j. days & $120 \pm 5$ & $119 \pm 6$ & $123 \pm 8$ & $123 \pm 6$ & $117 \pm 7$ & $122 \pm 8$ & $124 \pm 8$ & $124 \pm 7$ \\
\hline & & week & $17.0 \pm 0.7$ & $16.8 \pm 0.8$ & $17.5 \pm 1.2$ & $17.6 \pm 1.0$ & $16.6 \pm 0.9$ & $17.3 \pm 1.0$ & $17.8 \pm 1.2$ & $17.7 \pm 1.1$ \\
\hline \multirow{2}{*}{$\mathrm{Ph} 4$} & \multirow{2}{*}{ ВBCH 93} & j. days & $250 \pm 29$ & $243 \pm 12$ & $251 \pm 37$ & $259 \pm 16$ & $273 \pm 15$ & $271 \pm 21$ & $275 \pm 20$ & $265 \pm 17$ \\
\hline & & week & $36.0 \pm 3.9$ & $35.0 \pm 1.9$ & $36.1 \pm 5.2$ & $37.1 \pm 2.3$ & $39.1 \pm 2.0$ & $39.0 \pm 2.8$ & $39.5 \pm 2.6$ & $38.0 \pm 2.4$ \\
\hline \multirow{2}{*}{$\mathrm{Ph} 5$} & \multirow[b]{2}{*}{ ВВСН 97} & j. days & $310 \pm 10$ & $303 \pm 13$ & $311 \pm 11$ & $312 \pm 6$ & $323 \pm 8$ & $313 \pm 16$ & $309 \pm 11$ & $308 \pm 11$ \\
\hline & & week & $44.5 \pm 1.2$ & $43.5 \pm 1.9$ & $44.5 \pm 1.4$ & $44.7 \pm 0.8$ & $46.3 \pm 1.0$ & $44.8 \pm 2.0$ & $44.2 \pm 1.3$ & $44.0 \pm 1.2$ \\
\hline \multirow{2}{*}{ Ph6 } & \multirow{2}{*}{ ВBCH 511} & j. days & $97 \pm 6$ & $96 \pm 6$ & $104 \pm 4$ & $104 \pm 5$ & $100 \pm 5$ & $98 \pm 1$ & $103 \pm 6$ & $104 \pm 4$ \\
\hline & & week & $14.0 \pm 0.7$ & $13.8 \pm 0.8$ & $14.9 \pm 0.6$ & $14.9 \pm 0.7$ & $14.4 \pm 0.7$ & $14.0 \pm 0.0$ & $14.7 \pm 0.8$ & $14.9 \pm 0.7$ \\
\hline \multirow{2}{*}{$\mathrm{Ph} 7$} & \multirow{2}{*}{ ВBCH 512} & j. days & $110 \pm 6$ & $111 \pm 3$ & $116 \pm 6$ & $116 \pm 4$ & $108 \pm 5$ & $111 \pm 8$ & $113 \pm 3$ & $114 \pm 6$ \\
\hline & & week & $15.8 \pm 0.8$ & $15.8 \pm 0.4$ & $16.5 \pm 0.8$ & $16.5 \pm 0.5$ & $15.5 \pm 0.8$ & $15.8 \pm 1.0$ & $16.2 \pm 0.5$ & $16.2 \pm 0.7$ \\
\hline \multirow{2}{*}{$\mathrm{Ph} 8$} & \multirow{2}{*}{ BBCH 62} & j. days & $121 \pm 6$ & $120 \pm 5$ & $124 \pm 4$ & $126 \pm 4$ & $115 \pm 4$ & $119 \pm 7$ & $126 \pm 4$ & $127 \pm 4$ \\
\hline & & week & $17.2 \pm 0.8$ & $17.0 \pm 0.6$ & $17.6 \pm 0.5$ & $17.9 \pm 0.7$ & $16.4 \pm 0.5$ & $17.0 \pm 1.0$ & $17.8 \pm 0.5$ & $18.0 \pm 0.5$ \\
\hline \multirow{2}{*}{$\mathrm{Ph} 9$} & \multirow{2}{*}{ ВBCH 652} & j. days & $130 \pm 3$ & $132 \pm 3$ & $137 \pm 4$ & $138 \pm 4$ & $129 \pm 3$ & $133 \pm 4$ & $138 \pm 4$ & $139 \pm 3$ \\
\hline & & week & $18.6 \pm 0.6$ & $18.8 \pm 0.4$ & $19.6 \pm 0.5$ & $19.7 \pm 0.5$ & $18.4 \pm 0.5$ & $19.0 \pm 0.6$ & $19.7 \pm 0.5$ & $19.9 \pm 0.4$ \\
\hline \multirow[b]{2}{*}{ Ph10 } & \multirow[b]{2}{*}{ ВBCH 671} & j. days & $141 \pm 9$ & $140 \pm 4$ & $145 \pm 3$ & $145 \pm 3$ & $141 \pm 6$ & $144 \pm 3$ & $147 \pm 1$ & $148 \pm 7$ \\
\hline & & week & $20.2 \pm 1.3$ & $20.2 \pm 0.8$ & $20.8 \pm 0.5$ & $20.7 \pm 0.5$ & $20.1 \pm 1.0$ & $20.7 \pm 0.5$ & $21.0 \pm 0.0$ & $21.1 \pm 0.9$ \\
\hline \multirow{2}{*}{ Ph11 } & \multirow{2}{*}{ ВBCH 69} & j. days & $158 \pm 6$ & $156 \pm 7$ & $157 \pm 5$ & $157 \pm 6$ & $154 \pm 6$ & $154 \pm 8$ & $157 \pm 4$ & $159 \pm 8$ \\
\hline & & week & $22.4 \pm 0.9$ & $22.2 \pm 1.0$ & $22.4 \pm 0.7$ & $22.3 \pm 0.8$ & $22 \pm 0.8$ & $21.8 \pm 1.0$ & $22.3 \pm 0.5$ & $22.7 \pm 1.1$ \\
\hline
\end{tabular}


Table 8. Cont.

\begin{tabular}{|c|c|c|c|c|c|c|c|c|c|c|}
\hline \multirow{2}{*}{$\begin{array}{l}\text { No. of Phenological } \\
\text { Phase }\end{array}$} & \multirow{2}{*}{ BBCH code } & & \multicolumn{4}{|c|}{ High-rise Building Areas } & \multicolumn{4}{|c|}{ Water Areas } \\
\hline & & & Z1 & $\mathbf{Z 2}$ & $\mathbf{Z 3}$ & $\mathrm{Z4}$ & Z1 & $\mathbf{Z} 2$ & Z3 & $\mathrm{Z4}$ \\
\hline Ph1 & ВВСН 07 & $\begin{array}{l}\text { j. days } \\
\text { week }\end{array}$ & $\begin{array}{c}86 \pm 4 \\
12.4 \pm 0.5\end{array}$ & $\begin{array}{c}87 \pm 6 \\
12.5 \pm 0.8\end{array}$ & $\begin{array}{c}86 \pm 4 \\
12.5 \pm 0.6\end{array}$ & $\begin{array}{c}89 \pm 6 \\
13.0 \pm 0.8\end{array}$ & $\begin{array}{c}83 \pm 0 \\
12.0 \pm 0\end{array}$ & $\begin{array}{c}88 \pm 9 \\
12.7 \pm 1.2\end{array}$ & $\begin{array}{c}92 \pm 6 \\
13.2 \pm 0.8\end{array}$ & $\begin{array}{c}94 \pm 5 \\
13.5 \pm 0.7\end{array}$ \\
\hline $\mathrm{Ph} 2$ & ВBCH 11 & $\begin{array}{l}\text { j. days } \\
\text { week }\end{array}$ & $\begin{array}{c}95 \pm 4 \\
13.7 \pm 0.5\end{array}$ & $\begin{array}{c}94 \pm 5 \\
13.8 \pm 0.6\end{array}$ & $\begin{array}{c}95 \pm 8 \\
13.5 \pm 1.0\end{array}$ & $\begin{array}{c}100 \pm 3 \\
14.2 \pm 0.4\end{array}$ & $\begin{array}{c}96 \pm 6 \\
13.7 \pm 0.6\end{array}$ & $\begin{array}{c}101 \pm 4 \\
14.3 \pm 0.6\end{array}$ & $\begin{array}{c}101 \pm 4 \\
14.2 \pm 0.4\end{array}$ & $\begin{array}{c}101 \pm 4 \\
14.3 \pm 0.6\end{array}$ \\
\hline $\mathrm{Ph} 3$ & ВBCH 19 & $\begin{array}{l}\text { j. days } \\
\text { week }\end{array}$ & $\begin{array}{c}118 \pm 4 \\
16.7 \pm 0.5\end{array}$ & $\begin{array}{c}117 \pm 8 \\
16.7 \pm 1.0\end{array}$ & $\begin{array}{c}118 \pm 13 \\
16.8 \pm 1.8\end{array}$ & $\begin{array}{c}124 \pm 4 \\
17.6 \pm 0.5\end{array}$ & $\begin{array}{c}122 \pm 4 \\
17.3 \pm 0.6\end{array}$ & $\begin{array}{c}119 \pm 8 \\
17.0 \pm 1.0\end{array}$ & $\begin{array}{c}124 \pm 8 \\
17.8 \pm 1.3\end{array}$ & $\begin{array}{c}122 \pm 4 \\
17.3 \pm 0.6\end{array}$ \\
\hline $\mathrm{Ph} 4$ & ВBCH 93 & $\begin{array}{l}\text { j. days } \\
\text { week }\end{array}$ & $\begin{array}{c}260 \pm 30 \\
37.4 \pm 4.2\end{array}$ & $\begin{array}{c}266 \pm 20 \\
38.2 \pm 2.7\end{array}$ & $\begin{array}{l}276 \pm 18 \\
39 \pm 2.3\end{array}$ & $\begin{array}{c}261 \pm 17 \\
37.4 \pm 2.2\end{array}$ & $\begin{array}{c}280 \pm 0 \\
40.0 \pm 0.0\end{array}$ & $\begin{array}{c}272 \pm 0 \\
39.0 \pm 0.0\end{array}$ & $\begin{array}{c}255 \pm 22 \\
36.8 \pm 3.0\end{array}$ & $\begin{array}{c}266 \pm 24 \\
37.0 \pm 3.5\end{array}$ \\
\hline $\mathrm{Ph} 5$ & ВBCH 97 & $\begin{array}{l}\text { j. days } \\
\text { week }\end{array}$ & $\begin{array}{c}316 \pm 10 \\
45.3 \pm 1.4\end{array}$ & $\begin{array}{c}318 \pm 11 \\
45.7 \pm 1.6\end{array}$ & $\begin{array}{c}319 \pm 12 \\
45.8 \pm 1.8\end{array}$ & $\begin{array}{c}313 \pm 9 \\
45.0 \pm 1.4\end{array}$ & $\begin{array}{c}319 \pm 8 \\
46.3 \pm 1.2\end{array}$ & $\begin{array}{c}308 \pm 14 \\
44.3 \pm 2.3\end{array}$ & $\begin{array}{c}309 \pm 14 \\
44.4 \pm 1.9\end{array}$ & $\begin{array}{c}315 \pm 3 \\
45.0 \pm 0.0\end{array}$ \\
\hline Ph6 & ВВСН 511 & $\begin{array}{l}\text { j. days } \\
\text { week }\end{array}$ & $\begin{array}{c}99 \pm 6 \\
14.3 \pm 0.8\end{array}$ & $\begin{array}{c}101 \pm 9 \\
14.5 \pm 1.2\end{array}$ & $\begin{array}{c}95 \pm 7 \\
13.6 \pm 0.9\end{array}$ & $\begin{array}{c}104 \pm 8 \\
15.0 \pm 1.0\end{array}$ & $\begin{array}{c}96 \pm 6 \\
13.7 \pm 0.6\end{array}$ & $\begin{array}{l}101 \pm 3,5 \\
14.3 \pm 0.6\end{array}$ & $\begin{array}{c}105 \pm 5 \\
15.0 \pm 0.7\end{array}$ & $\begin{array}{c}105 \pm 5 \\
14.7 \pm 0.6\end{array}$ \\
\hline Ph7 & ВBCH 512 & $\begin{array}{l}\text { j. days } \\
\text { week }\end{array}$ & $\begin{array}{c}111 \pm 6 \\
15.9 \pm 0.9 \\
\end{array}$ & $\begin{array}{c}109 \pm 9 \\
15.7 \pm 1.2 \\
\end{array}$ & $\begin{array}{c}106 \pm 6 \\
15.4 \pm 0.9 \\
\end{array}$ & $\begin{array}{c}117 \pm 5 \\
16.6 \pm 0.5\end{array}$ & $\begin{array}{c}107 \pm 4 \\
15.3 \pm 0.6 \\
\end{array}$ & $\begin{array}{l}112 \pm 8,0 \\
16.0 \pm 1.0\end{array}$ & $\begin{array}{c}115 \pm 5 \\
16.4 \pm 0.5\end{array}$ & $\begin{array}{c}118 \pm 7 \\
16.7 \pm 1.2\end{array}$ \\
\hline Ph8 & ВBCH 62 & $\begin{array}{l}\text { j. days } \\
\text { week }\end{array}$ & $\begin{array}{c}120 \pm 6 \\
17.0 \pm 0.8\end{array}$ & $\begin{array}{c}120 \pm 9 \\
17.0 \pm 1.2\end{array}$ & $\begin{array}{c}117 \pm 13 \\
16.6 \pm 1.8\end{array}$ & $\begin{array}{c}126 \pm 3 \\
17.8 \pm 0.4\end{array}$ & $\begin{array}{c}122 \pm 4 \\
17.3 \pm 0.6\end{array}$ & $\begin{array}{c}124 \pm 6 \\
17.7 \pm 1.2\end{array}$ & $\begin{array}{c}127 \pm 5 \\
18.0 \pm 0.7\end{array}$ & $\begin{array}{c}130 \pm 7 \\
18.3 \pm 1.2\end{array}$ \\
\hline $\mathrm{Ph} 9$ & ВBCH 652 & $\begin{array}{l}\text { j. days } \\
\text { week }\end{array}$ & $\begin{array}{c}134 \pm 6 \\
19.0 \pm 0.8\end{array}$ & $\begin{array}{c}134 \pm 8 \\
19.0 \pm 1.1\end{array}$ & $\begin{array}{c}137 \pm 6 \\
19.4 \pm 0.9\end{array}$ & $\begin{array}{c}137 \pm 5 \\
19.6 \pm 0.5\end{array}$ & $\begin{array}{c}131 \pm 0 \\
19.0 \pm 0.0\end{array}$ & $\begin{array}{c}131 \pm 7 \\
18.7 \pm 1.2\end{array}$ & $\begin{array}{c}136 \pm 9 \\
19.4 \pm 1.1\end{array}$ & $\begin{array}{c}142 \pm 7 \\
20.0 \pm 1.0\end{array}$ \\
\hline Ph10 & ВВСН 671 & $\begin{array}{l}\text { j. days } \\
\text { week }\end{array}$ & $\begin{array}{c}145 \pm 4 \\
20.7 \pm 0.5\end{array}$ & $\begin{array}{c}145 \pm 3 \\
20.8 \pm 0.4\end{array}$ & $\begin{array}{c}142 \pm 6 \\
20.4 \pm 0.9\end{array}$ & $\begin{array}{c}142 \pm 4 \\
20.4 \pm 0.5\end{array}$ & $\begin{array}{c}145 \pm 0 \\
21.0 \pm 0.0\end{array}$ & $\begin{array}{c}149 \pm 12 \\
21.3 \pm 1.5\end{array}$ & $\begin{array}{c}150 \pm 7 \\
21.4 \pm 0.9\end{array}$ & $\begin{array}{c}145 \pm 4 \\
20.5 \pm 0.7\end{array}$ \\
\hline Ph11 & BBCH 69 & $\begin{array}{l}\text { j. days } \\
\text { week }\end{array}$ & $\begin{array}{c}157 \pm 4 \\
22.4 \pm 0.5\end{array}$ & $\begin{array}{c}163 \pm 11 \\
23.2 \pm 1.4\end{array}$ & $\begin{array}{c}154 \pm 8 \\
22.0 \pm 1.0\end{array}$ & $\begin{array}{c}155 \pm 7 \\
22.2 \pm 0.9\end{array}$ & $\begin{array}{c}162 \pm 0 \\
23.0 \pm 0.0\end{array}$ & $\begin{array}{c}161 \pm 16 \\
23.0 \pm 2.0\end{array}$ & $\begin{array}{c}162 \pm 9 \\
23.0 \pm 1.2\end{array}$ & $\begin{array}{c}156 \pm 4 \\
22.3 \pm 0.6\end{array}$ \\
\hline
\end{tabular}


Ph4 was observed on average in weeks 36-37 along communication routes and in green areas in the 39th week of the year, regardless of the distance of the trees from the center (Table 8). The variability of the Ph4 phase was greater in the areas of communication and the differences ranged from 2 to even 5 weeks for trees growing in the Z3 zone. In extreme cases, for trees growing along communication routes, the fall of leaves was noted in week 29 in zone Z1 and in week 25 in zone Z3. In trees growing in green areas, the variation in the appearance of the phase was smaller and ranged from 2 to 3 weeks, depending on their location from the city center In the case of high-rise buildings, the Ph4 phase in zone $\mathrm{Z1}$ and $\mathrm{Z} 4$ was, on average, in the first half of the 37th week, while in trees growing in zone Z4, the variability of its occurrence was 2 weeks and in zone Z1, as much as 4 weeks. In the case of trees growing at reservoirs and watercourses, the beginning of leaf fall occurred on average in the 40th week in zone Z1.

The leaves lasted longer on trees growing near high-rise buildings and in green areas when compared to trees growing near communication routes (Table 8). The difference was that trees growing near tall buildings were characterized by a greater phase variation compared to trees growing in green areas. In green areas at a distance of up to $1 \mathrm{~km}(\mathrm{Z1})$, this phase lasted approx. 1.5 weeks longer compared to trees growing in green areas in other zones.

It can be seen that in trees growing along communication routes in zones Z3 and Z4, the Ph7 phase occurred on average about a week later than in zones Z1 and Z2. Similar observations occurred for high-rise buildings but the differences in this case were half a week. In green areas, the Ph7 phase occurred on average half a week later for each subsequent zone.

\section{Discussion}

Our study presents the results of one vegetation period, such as in Schmidlin [68], Zhang et al. [28] or Jochner et al. [30]; however, as shown by Zipper et al. [27], the magnitude of changes in the phenology associated with UHI is strongly determined by the prevailing weather conditions, which may lead to generalization of the results. Therefore, it is necessary to continue the observations taking into account air temperature and humidity, precipitation or air relative humidity. On the other hand, Zipper et al. [27] showed that despite some differences in the results from single years of observation, the results taking into account spatial patterns may be the same over the years. Similarly, Buyantuyev and $\mathrm{Wu}$ [12] showed that phenological diversity results to a large extent from the degree of urbanization and is not synchronized with climatic variability. Ding et al. [38] suggests that urbanization, through surface warming, compounds the effect of climate change on vegetation phenology.

The acceleration of the initial phases and the extension of the growing season in the city center, which we have seen in Wrocław, is consistent with the results obtained for Munich in Germany [57], for Campinas in Brazil [30], for cities in Yangtze River Delta in China [38] or for Madison in the USA [27]. In our studies, based on average values, it was observed that the growing season for horse chestnut in the center of the city lasted an average of two weeks longer than in peripheral areas situated more than $5 \mathrm{~km}$ from the center. Zipper et al. [27] observed, on the basis of studies using remote sensing, an extension of the growing season by 10-25 days and on the basis of air temperatures, by approx. 8-11 days. Zipper et al. [27], who based their research on remote sensing and assessment of the degree of greening, suggest that the acceleration of the growing season and its extension in the city center compared to peripheral areas may be related to species diversity. According to these authors, the introduced winter-hardy species are often used in the city center, whereas the native, deciduous species appear in rural areas. The results obtained in this study on the basis of the observation of the horse chestnut confirm the spatial relationship without any relation to species diversity and are consistent with the results of other researchers around the world [44]. However, it was noticed that the extension of the growing season is related to the earlier development of plants in the spring (starting phases) in the center zone compared to the peripheral areas, with a similar end time to the growing season. The premature defoliation of horse chestnut trees is also influenced by Cameraria ohridella and the authors' observations show that in the city center, where leaves fell from all zones the latest, 
the degree of infection with Cameraria ohridella is lower than in the peripheries. This may be related to the greater sterility of central city areas compared to the peripheries, where the leaves, in which the larvae of pests spend the winter, are more frequently and systematically removed.

Jochner et al. [30] showed that temperate zone plants in cities bloom earlier than plants in rural areas due to higher local temperatures, this was especially noticeable for the blooming phenophases of warty birch in Munich. This is also confirmed by the results presented in this study for trees growing in zones up to $2 \mathrm{~km}$ from the city center, which bloomed earlier than trees located $5 \mathrm{~km}$ from the city center The influence of air temperature on the flowering rate is also visible in the waterside areas; naturally cooler with higher humidity and lower water vapor deficit in the air, where flowering was observed at the latest phase in relation to other forms of land cover.

Li et al. [34] and Wohlfahrt et al. [69], based on their work, believe that the effects of UHI (measured by the daily earth surface temperature) alone cannot explain the overall impact of the degree of urbanization on plant phenology. This suggests that urbanization also influences plant phenology through other mechanisms, which is why the research also considered the form of land use in which the specimens are grown. On the basis of phenological observations carried out in Wrocław, the results obtained for the assessment of the impact of individual types of terrain were statistically confirmed only for areas located near communication routes and green areas. However, the analysis of the timing of the occurrence of individual phenological phases shows that the course of phenophases for green areas and areas near reservoirs and watercourses (although the work of Schatz and Kucharik [70] showed that the zone of water reservoir influence on temperature is relatively small-it has the strongest impact in the zone up to $100 \mathrm{~m}$ ), in relation to built-up areas and surrounded by impermeable surfaces, is characterized by less variability.

Despite the initially similar development of trees in all the considered forms of land cover, a delay in the appearance of the final phases (leaf fall) for green areas is noticeable compared to street areas. The results of Zipper et al. [27] also showed intermediate results for the start and end of the growing season based on air temperatures for park areas versus urban and rural areas. As suggested by Yu and Hien [71], Feyisa et al. [72] and Zipper [27], green areas and urban parks are subject to both the urban heat island effect, which raises the temperature in relation to the rural environment and the cool island effect, which lowers the temperature in relation to their urban surroundings. Green areas are characterized by lower air temperature fluctuations during the day and less heating of the ground surface due to shading.

The phenological development of plants is related not only to temperatures-it is influenced by the growing conditions of the tree, the individual size and age of the tree, the tree vitality and water stress [73-76]. Urban trees often experience the negative effects of excessive soil compaction [77] and too little growth space with limited availability of water and nutrients [78], and, as a consequence, it affects the life processes of plants. Sobolewski and Chohura [79] showed that soils in road lanes in Wrocław are characterized by a low level of nitrogen available for plants and high levels of $\mathrm{Ca}, \mathrm{Na}$ and $\mathrm{Cl}$, which in turn has an impact on the nutritional status of trees. Łukasiewicz and Oleksy [80] showed that the size of the soil surface around horse chestnut trees directly influences the differentiation of average temperatures (including maximum and minimum temperatures), humidity and insufficient air humidity as well as the intensity of transpiration. The authors also indicate that in an urbanized environment, a sufficiently large, unpaved soil surface affects, among other things, the length of the foliage phase, which our research supports. These aspects may explain our observation of extreme cases, when the process of defoliation of leaves of trees began already in the 29th week of the year. Jochner et al. [53] showed that the increase in the concentration of O3, NO2, NOx and PM, significantly delayed the phenological phases of warty birch, horse chestnut and common hazel, these relationships were more noticeable in the city center than in non-urban areas. However, Borowski and Pstragowska [81] drew attention to the delay of the cracking of lime buds growing in road lanes and thus delay in phenological development as a result of their damage by salt aerosol depositing on their surface during winters. This study may explain why, in our observations of trees growing 
along the routes, developed later. Chen et al. [82] have shown, however, that heating of the surface of concrete/impermeable surfaces may affect the temperature rise of the soil, while the increased soil temperature accelerates the breakage of leaf buds in Fraxinus chinensis. Shashua-Bar et al. [83] showed that reducing traffic by half reduces the ambient temperature and therefore intensive traffic increases the local temperature, which may be an additional factor supporting faster defoliation of trees in road lanes. Some studies suggest that elevated $\mathrm{CO} 2$ levels in the city may delay the coloration and aging of tree leaves in autumn [84]. Similar observations were made by Reference [12] who indicate that urban ban lighting may extend the defoliation process over time. The aforementioned processes may explain the complexity of the impact of numerous independent factors influencing the phenology of plants in urban areas, which would explain the observations concerning the extended vegetation period in the city center as well as the shortened vegetation period in road lanes.

\section{Conclusions}

- Patterns of the effects of distance and surroundings on the phenology of the horse chestnut have been documented mainly for the initial and final stages of foliage and initial stages of flowering.

- The surroundings and the distance from the city center affect the phenology of trees of the studied species in urbanized areas, which results in the delay and acceleration of individual phenological phases, however, due to the heterogeneous structure of urban areas and its geometry, research in this area is difficult and laborious.

- The results obtained on the basis of phenological observations carried out in 2017 in Wrocław confirmed the extension of the period of vegetation in the city center in relation to its peripheries.

- Trees growing in road lanes entered the vegetation period later and defoliated faster, which confirms the negative impact of street conditions on the development of trees in urban space. Thus, the growing season in road lanes is shorter and due to the 1-year observation period, it is justified to conduct further observations.

- The article may become the next step in improving the methodology of carrying out phenological observations in urban areas, taking into account its characteristic heterogeneous spatial structure.

- Research in this area should be continued, the results of several years of observation may enrich knowledge on the impact of local climate and urbanization on urban trees.

Supplementary Materials: The following are available online at http://www.mdpi.com/1999-4907/11/12/1261/s1, Table S1: OBSERVATION SHEET.

Author Contributions: Conceptualization, I.D.O.-S. and R.K.S.; Methodology, I.D.O.-S.; Validation, I.O.-S and R.K.S.; Formal Analysis, R.K.S.; Investigation, J.L. and P.K.; Data Curation, R.K.S., J.L. and P.K.; Writing-Original Draft Preparation, I.D.O.-S. and R.K.S., Writing-Review \& Editing, R.K. and I.D.O.-S.; Visualization, I.D.O.-S. and J.L. Supervision, I.D.O.-S.; Project Administration, I.OS.; Funding Acquisition, I.D.O.-S. All authors have read and agreed to the published version of the manuscript.

Funding: This research received no external funding.

Conflicts of Interest: The authors declare no conflict of interest.

\section{References}

1. Baker, L.A.; Brazel, A.J.; Selover, N.; Martin, C.; McIntyre, N.; Steiner, F.R.; Nelson, A.; Musacchio, L. Urbanization and warming of Phoenix (Arizona, USA): Impacts, feedbacks and mitigation. Urban Ecosyst. 2002, 6, 183-203. [CrossRef]

2. Miles, L.; Grainger, A.; Phillips, O. The impact of global climate change on tropical forest biodiversity in Amazonia. Glob. Ecol. Biogeogr. 2004, 13, 553-565. [CrossRef]

3. Visser, M.E.; Both, C. Shifts in phenology due to global climate change: The need for a yardstick. Proc. R. Soc. B 2005, 272, 2561-2569. [CrossRef] [PubMed]

4. Luo, Z.; Sun, O.J.; Ge, Q.; Xu, W.; Zheng, J. Phenological responses of plants to climate change in an urban environment. Ecol. Res. 2007, 22, 507-514. [CrossRef] 
5. Körner, C.; Basler, D. Phenology under global warming. Science 2010, 327, 1461-1462. [CrossRef] [PubMed]

6. Fu, Y.H.; Zhao, H.; Piao, S.; Peaucelle, M.; Peng, S.; Zhou, G.; Ciais, P.; Huang, M.; Menzel, A.; Penuelas, J.; et al. Declinig global Warming effects on the phenology on the phenology of spring leaf unfolding. Nature 2015, 526, 104-119. [CrossRef]

7. Wang, J.; Yan, Z.W. Urbanization-related warming in local temperature records: A review. Atmos. Ocean. Sci. Lett. 2016, 9. [CrossRef]

8. Zhou, D.; Zhao, S.; Zhang, L.; Liu, S. Remotely sensed assessment of urbanization effects on vegetation phenology in China's 32 major cities. Remote Sens. Environ. 2016, 176, 272-281. [CrossRef]

9. Li, X.; Zhou, Y.; Asrar, G.R.; Mao, J.; Li, X. Response of vegetation phenology to urbanization in the conterminous United States. Glob. Chang. Biol. 2017, 23, 2818-2830. [CrossRef]

10. Villalobos-Jiménez, G.; Hassall, C. Effects of the urban heat island on the phenology of Odonata in London, UK. Int. J. Biometeorol. 2017, 61, 1337-1346. [CrossRef]

11. Qiu, J.; Yang, X.; Cao, B.; Chen, Z.; Li, Y. Effects of Urbanization on Regional Extreme-Temperature Changes in China, 1960-2016. Sustainability 2020, 12, 6560. [CrossRef]

12. Buyantuyev, A.; Wu, J. Urbanization diversifies land surface phenology in arid environments: Interactions among vegetation, climatic variation, and land use pattern in the Phoenix metropolitan region, USA. Landsc. Urban Plan. 2012, 105, 149-159. [CrossRef]

13. Škvareninová, J.; Tuhárska, M.; Škvarenina, J.; Babálová, D.; Slobodníková, L.; Slobodník, B.; Středová, H.; Mind'aš, J. Effects of light pollution on tree phenology in the urban environment. Morav. Geogr. Rep. 2017, 25, 282-290. [CrossRef]

14. Ffrench-Constant, R.H.; Somers-Yeates, R.; Bennie, J.; Economou, T.; Hodgso, D.; Spalding, A.; McGregor, P.K. Light pollution is associated with earlier tree budburst across the United Kingdom. Proc. R. Soc. B Biol. Sci. 2016, 283, 20160813. [CrossRef] [PubMed]

15. Ballester, J.; Rodó, X.; Giorgi, F. Future changes in Central Europe heat waves expected to mostly follow summer mean warming. Clim. Dynam. 2010, 35, 1191-1205. [CrossRef]

16. Seto, K.C.; Fragkias, M.; Güneralp, B.; Reilly, M.K. A meta-analysis of global urban land expansion. PLoS ONE 2011, 6, e23777. [CrossRef]

17. Klemm, W.; Heusinkveld, B.G.; Lenzholzer, S.; van Hove, B. Street greenery and its physical and psychological impact on thermal comfort. Landsc. Urban Plan. 2015, 138, 87-98. [CrossRef]

18. McCarthy, M.P.; Best, M.J.; Betts, R.A. Climate change in cities due to global warming and urban effects. Geophys. Res. Lett. 2010, 37, L09705. [CrossRef]

19. Oleson, K.W.; Bonan, G.B.; Feddema, J.; Jackson, T. An examination of urban heat island characteristics in a global climate model. Int. J. Climatol. 2010, 31, 1848-1865. [CrossRef]

20. Santamouris, M. Cooling the cities-A review of reflective and green roof mitigation technologies to fight heat island and improve comfort in urban environments. Sol. Energy 2014, 103, 682-703. [CrossRef]

21. Mimet, A.; Pellissier, V.; Quenol, H.; Aguejdad, R.; Dubreuil, V.; Roze, F. Urbanisation induces early flowering: Evidence from Platanusacerifolia and Prunuscerasus. Int. J. Biometeorol. 2009, 53, 287-298. [CrossRef] [PubMed]

22. Richardson, A.D.; Keenan, T.F.; Migliavacca, M.; Ryu, Y.; Sonnentag, O.; Toomey, M. Climate change, phenology, and phenological control of vegetation feedbacks to the climate system. Agric. For. Meteorol. 2013, 169, 156-173. [CrossRef]

23. Akbari, H.; Pomerantz, M.; Taha, H. Cool surfaces and shade trees to reduce energy use and improve air quality in urban areas. Sol. Energy 2001, 70, 295-310. [CrossRef]

24. Cardelino, C.A.; Chameides, W.L. Natural hydrocarbons, urbanization, and urban ozone. J. Geophys. Res. Atmos. 1990, 95, 13971-13979. [CrossRef]

25. Founda, D.; Pierros, F.; Petrakis, M.; Zerefos, C. Interdecadal variations and trends of the Urban Heat Island in Athens (Greece) and its response to heatwaves. Atmos. Res. 2015, 161, 1-13. [CrossRef]

26. Wilby, R.L. Past and projected trends in London's urban heat island. Weather 2003, 58, 251-260. [CrossRef]

27. Zipper, S.C.; Schatz, J.; Singh, A.; Kucharik, C.J.; Townsend, P.A.; Loheide, S.P. Urban heat island impacts on plant phenology: Intra-urban variability and response to land cover. Environ. Res. Lett. 2016, 11, 054023. [CrossRef]

28. Zhang, X.; Friedl, M.A.; Schaaf, C.B.; Strahler, A.; Hand Schneider, A. The footprint of urban climates on vegetation phenology. Geophys. Res. Lett. 2004, 31, L12209. [CrossRef] 
29. Jochner, S.C.; Sparks, T.H.; Estrella, N.; Menzel, A. The influence of altitude and urbanisation on trends and mean dates in phenology (1980-2009). Int. J. Biometeorol. 2012, 56, 387-394. [CrossRef]

30. Jochner, S.; Alves-Eigenheer, M.; Menzela, A.; Morellato, L.P.C. Using phenology to assess urban heat islands in tropical and temperate regions. Int. J. Climatol. 2013, 33, 3141-3151. [CrossRef]

31. Jochner, S.; Menzel, A. Urban phenological studies-Past, present, future. Environ. Pollut. 2015, 203, $250-261$. [CrossRef] [PubMed]

32. Cohen, B. Urbanization in developing countries: Current trends, future projections, and key challenges for sustainability. Technol. Soc. 2006, 28, 63-80. [CrossRef]

33. Gazal, R.; White, M.A.; Gillies, R.; Rodemaker, E.; Sparrow, E.; Gordon, L. GLOBE students, teachers, and scientists demonstrate variable differences between urban and rural leaf phenology. Glob. Chang. Biol. 2008, 14, 1568-1580. [CrossRef]

34. Li, D.; Stucky, B.J.; Deck, J.; Baiser, B.; Guralnick, R.P. The effect of urbanization on plant phenology depends on regional temperature. Nat. Ecol. Evol. 2019, 3, 1661-1667. [CrossRef]

35. White, M.A.; Nemani, R.R.; Thornton, P.E.; Running, S.W. Satellite Evidence of Phenological Differences Between Urbanized and Rural Areas of the Eastern United States Deciduous Broadleaf Forest. Ecosystems 2002, 5, 260-273. [CrossRef]

36. Neil, K.L.; Landrum, L.; Wu, J. Effects of urbanization on flowering phenology in the metropolitan Phoenix region of USA: Findings from herbarium records. J. Arid Environ. 2010, 74, 440-444. [CrossRef]

37. Jeong, J.H.; Ho, C.H.; Linderholm, H.W.; Jeong, S.J.; Chen Dand Choi, Y.S. Impact of urban warming on earlier spring flowering in Korea. Int. J. Climatol. 2011, 31, 1488-1497. [CrossRef]

38. Ding, H.; Xu, L.; Elmore, A.J.; Shi, Y. Vegetation Phenology Influenced by Rapid Urbanization of The Yangtze Delta Region. Remote Sens. 2020, 12, 1783. [CrossRef]

39. Moser-Reischl, A.; Uhl, E.; Rötzer, T.; Biber, P.; van Con, T.; Thanh Tan, N.; Pretzsch, H. Effects of the urban heat island and climate change on the growth of Khaya senegalensis in Hanoi, Vietnam. For. Ecosyst. 2018, 5, 37. [CrossRef]

40. Fotiou, C.; Damialis, A.; Krigas, N.; Halley, J.M.; Vokou, D. Parietaria judaica flowering phenology, pollen production, viability and atmospheric circulation, and expansive ability in the urban environment: Impacts of environmental factors. Int. Soc. Biometeorol. 2011, 55, 35-50. [CrossRef]

41. Smoliak, B.V.; Snyder, P.K.; Twine, T.E.; Mykleby, P.M.; Hertel, W.F. Dense network observations of the Twin Cities canopylayer urban heat island. J. Appl. Meteorol. Climatol. 2015, 54, 1899-1917. [CrossRef]

42. Elmore, A.J.; Guinn, S.M.; Minsley, B.J.; Richardson, A.D. Landscape controls on the timing of spring, autumn, and growing season length in mid-Atlantic forests. Glob. Chang. Biol. 2012, 18, 656-674. [CrossRef]

43. Walker, J.J.; de Beurs, K.M.; Henebry, G.M. Land surface phenology along urban to rural gradients in the US Great Plains. Remote Sens. Environ. 2015, 165, 42-52. [CrossRef]

44. Fisher, J.I.; Mustard, J.F.; Vadeboncoeur, M.A. Green leaf phenology at Landsat resolution: Scaling from the field to the satellite. Remote Sens. Environ. 2006, 100, 265-279. [CrossRef]

45. Yang, L.; Niyogi, D.; Tewari, M.; Aliaga, D.; Chen, F.; Tian, F.; Ni, G. Contrasting impacts of urban forms on the future thermal environment: Example of Beijing metropolitan area. Environ. Res. Lett. 2016, 11, 034018. [CrossRef]

46. Masiero, E.; Souza, L. Improving urban thermal profile with trees and water features. Urban Des. Plan. 2015, 169, 66-77. [CrossRef]

47. Dubicki, A.; Dubicka, M.; Szymanowski, M. Klimat Wrocławia [In:] Środowisko Wrocławia. Informator o stanie środowiska Wrocławia. 2002, pp. 9-25. Available online: http://eko.org.pl/wroclaw/pdf/klimat.pdf (accessed on 26 April 2018).

48. Kalbarczyk, R.; Kalbarczyk, E.; Ziemiańska, M.; Raszka, B. Assessment of air thermal conditions in the lowland part of South-Western Poland for agriculture development purposes. Atmosphere 2018, 9, 215. [CrossRef]

49. Instytutu Meteorologii i Gospodarki Wodnej-Państwowego Instytutu Badawczego. Available online: https://danepubliczne.imgw.pl/apiinfo (accessed on 16 April 2019).

50. Szymanowski, M.; Kryza, M. Local regression models for spatial interpolation of urban heat island-An example from Wrocław, SW Poland. Theor. Appl. Climatol. 2012, 108, 53-71. [CrossRef]

51. Oleksyn, J.; Kloeppel, B.D.; Łukasiewicz, S.; Karolewski, P.; Reich, P.B. Ecophysiology of horse chestnut (Aesculus hippocastanum L.) in degraded and restored urban sites. Pol. J. Ecol. 2007, 55, 245-260. 
52. Czernecki, B.; Jabłońska, K. Reconstruction of late spring phenophases in Poland and their response to climate change, 1951-2014. Acta Agrobot. 2016, 65, 1671-1686. [CrossRef]

53. Jochner, S.; Markevych, J.; Beck, I.; Traidl-Hoffmann, C.; Heinrich, J.; Menzel, A. The effects of short- and long-term air pollutants on plant phenology and leaf characteristics. Environ. Pollut. 2015, 206, 382-389. [CrossRef] [PubMed]

54. Roberts, A.M.I.; Tansey, C.; Smithers, R.J.; Phillimore, A.B. Predicting a change in the order of spring phenology in temperate forests. Glob. Chang. Biol. 2015, 21, 2603-2611. [CrossRef] [PubMed]

55. Wittich, K.P.; Liedtke, M. Shifts in plant phenology: A look at the sensitivity of seasonal phenophases to temperature in Germany. Int. J. Climatol. 2015, 35, 3991-4000. [CrossRef]

56. Sparks, T.H.; Górska-Zajączkowska, M.; Wójtowicz, W.; Tryjanowski, P. Phenological changes and reduced seasonal synchrony in Western Poland. Int. J. Biometeorol. 2011, 55, 447-453. [CrossRef] [PubMed]

57. Jochner, S.C.; Beck, I.; Behrendt, H.; Traidl-Hoffmann, C.; Menzel, A. Effects of extreme spring temperatures on urban phenology and pollen production: A case study in Munich and Ingolstadt. Inter Res. Sci. Publ. 2011, 49, 101-112. [CrossRef]

58. Menzel, A.; Sparks, T.T.; Estrella, N.; Koch, E.; Aasa, A.; Ahas, R.; Alm-Kubler, K.; Bissolli, P.; Bratislavska, O.; Briede, A.; et al. European phenological response to climate change matches the Warming pattern. Glob. Chang. Biol. 2006, 12, 1969-1976. [CrossRef]

59. Schleip, C.; Menzel, A.; Estrella, N.; Dose, V. The use of Bayesian analysis to detect recent changes in phenological events throughout the year. Agric. For. Meteorol. 2006, 141, 179-191. [CrossRef]

60. Salleo, S.; Nardini, A.; Raimondo, F.; Lo Gullo, M.A.; Pace, F.; Giacomich, P. Effect of defoliation caused by the leaf miner Cameraria ohridella on wood production and efficiency in Aesculus hippocastanum growing in north-eastern Italy. Trees 2003, 17, 367-375. [CrossRef]

61. Urban Atlas-Copernicus Land Monitoring Service. Available online: https://land.copernicus.eu/local/urbanatlas/urban-atlas-2006 (accessed on 12 April 2017).

62. Finn, G.A.; Straszewski, A.E.; Peterson, V. A general growth stage key for describing trees and woody plants. Ann. App. Biol. 2007, 151, 127-131. [CrossRef]

63. Babálová, D.; Škvareninová, J.; Fazekaš, J.; Vyskot, I. The dynamics of the phenological development of four woody species in south-west and central Slovakia. Sustainability 2018, 10, 1497. [CrossRef]

64. Lukasová, V.; Bucha, T.; Škvareninová, J.; Škvarenina, J. Validation and Application of European Beech Phenological Metrics Derived from MODIS Data along an Altitudinal Gradient. Forests 2019, 10, 60. [CrossRef]

65. Stratópoulos, L.M.F.; Zhang, C.; Duthweiler, S.; Häberle, K.H.; Rötzer, T.; Xu, C.; Pauleit, S. Tree species from two contrasting habitats for use in harsh urban environments respond differently to extreme drought. Int. J. Biometeorol. 2019, 63, 197-208. [CrossRef] [PubMed]

66. Delgado, P.H.; Aranguren, M.; Reig, C.; Galvan, D.F.; Mesejo, C.; Fuentes, A.M.; Agusti, M. Phenological growth stages of mango (Mangifera indica L.) according to the BBCH scale. Sci. Hortic. 2011, 130, 536-540. [CrossRef]

67. Cosmulescu, S.; Scrieciu, F. Development of vegetation stages in medlar genotypes (Mespilus germanica L.) coded and described according to the BBCH scale. Biharean Biol. 2019, 14, 116-119.

68. Schmidlin, T. The Urban Heat-Island at Toledo. Ohio J. Sci. 1989, 89, 38-41.

69. Wohlfahrt, G.; Tomelleri, E.; Hammerle, A. The urban imprint on plant phenology. Nat. Ecol. Evol. 2019, 3, 1668-1674. [CrossRef] [PubMed]

70. Schatz, J.; Kucharik, C.J. Seasonality of the urban heat Island effect in Madison, Wisconsin. J. App. Meteorol. Climatol. 2014, 53, 2371-2386. [CrossRef]

71. Yu, C.; Hien, W.N. Thermal benefits of city parks. Energy Build. 2006, 38, 105-120. [CrossRef]

72. Feyisa, G.L.; Dons, K.; Meilby, H. Efficiency of parks in mitigating urban heat island effect: An example from Addis Ababa. Landsc. Urban Plan. 2014, 123, 87-95. [CrossRef]

73. Yoon, T.K.; Park, C.W.; Lee, S.J.; Ko, S.; Kim, K.N.; Son, Y.; Lee, K.H.; Oh, S.; Lee, W.K.; Son, Y. Allometric equations for estimating the aboveground volume of five common urban street tree species in Daegu, Korea. Urban For. Urban Green. 2013, 12, 344-349. [CrossRef]

74. Konarska, J.; Uddling, J.; Holmer, B.; Lutz, M.; Lindberg, F.; Pleijel, H.; Thorsson, S. Transpiration of urban trees and its cooling effect in a high latitude city. Int. J. Biometeorol. 2016, 60, 159-172. [CrossRef] [PubMed] 
75. Moser, A.; Rötzer, T.; Pauleit, S.; Pretzsch, H. Structure and ecosystem services of small-leaved lime (Tilia cordata mill.) and black locust (Robinia pseudoacacia L.) in urban environments. Urban For. Urban Green. 2015, 14, 1110-1121. [CrossRef]

76. Rahman, M.A.; Moser, A.; Rötzer, T.; Pauleit, S. Microclimatic differences and their influence on transpirational cooling of Tilia cordata in two contrasting street canyons in Munich, Germany. Agric. For. Meteorol. 2017, 232, 443-456. [CrossRef]

77. Bartens, J.; Day, S.D.; Harris, J.R.; Dove, J.E.; Wynn, T.M. Can urban tree roots improve infiltration through compacted subsoils for storm water management? J. Environ. 2008, 37, 2048-2057. [CrossRef]

78. Rahman, M.A.; Stringer, P.; Ennos, A.R. Effect of pit design and soil composition on performance of Pyrus calleryana street trees in the establishment period. Arboric. Urban For. 2013, 39, 256-266.

79. Sobolewski, R.; Chohura, P. Właściwości chemiczne gleb jako czynnik decydujacy o stanie odżywienia drzew. Zeszyty Naukowe Uniwersytetu Przyrodniczego we Wroctawiu 2015, 614, 61-73.

80. Łukasiewicz, S.; Oleksyn, J. Rekompensujący wpływ wolnej, nieutwardzonej powierzchni gleby wokół drzew, na ich rozwój w warunkach środowiska miejskiego, na przykładzie kasztanowca białego Aesculus hippocastanum L. Badania Fizjograficzne B 2008, 3, 155-165.

81. Borowski, J.; Pstragowska, M. Effect of street conditions, including saline aerosol, on growth of the Small-leaved limes. Rocznik Polskiego Towarzystwa Dendrologicznego 2010, 58, 15-24.

82. Chen, Y.; Wang, X.; Jiang, B.; Yang, N.; Li, L. Pavement induced soil warming accelerates leaf budburst of ash trees. Urban For. Urban Green. 2016, 16, 36-42. [CrossRef]

83. Shashua-Bar, L.; Tsiros, I.X.; Hoffman, M. Passive cooling design options to ameliorate thermal comfort in urban streets of a Mediterranean climate (Athens) under hot summer conditions. Build. Environ. 2012, 57, 110-119. [CrossRef]

84. Taylor, G.; Tallis, M.J.; Giardina, C.P.; Percy, K.E.; Miglietta, F.; Gupta, P.S.; Scarascia-Mugnozza, G.E. Future atmospheric $\mathrm{CO}_{2}$ leads to delayed autumnal senescence. Glob. Chang. Biol. 2008, 14, 264-275. [CrossRef]

Publisher's Note: MDPI stays neutral with regard to jurisdictional claims in published maps and institutional affiliations.

(C) 2020 by the authors. Licensee MDPI, Basel, Switzerland. This article is an open access article distributed under the terms and conditions of the Creative Commons Attribution (CC BY) license (http://creativecommons.org/licenses/by/4.0/). 